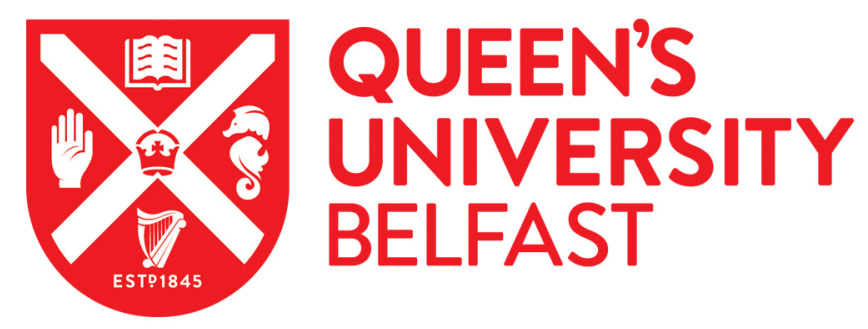

\title{
Detailed characterisation of STC-1 cells and the pGIP/Neo sub-clone suggests the incretin hormones are translationally regulated
}

Gillespie, A. L., Pan, X., Marco-Ramell, A., Meharg, C., \& Green, B. D. (2017). Detailed characterisation of STC1 cells and the pGIP/Neo sub-clone suggests the incretin hormones are translationally regulated. Peptides, 96, 20-30. https://doi.org/10.1016/j.peptides.2017.08.010

\section{Published in:}

Peptides

\section{Document Version:}

Peer reviewed version

Queen's University Belfast - Research Portal:

Link to publication record in Queen's University Belfast Research Portal

\section{Publisher rights}

(c) 2017 Elsevier Inc. All rights reserved

This manuscript version is made available under the CC-BY-NC-ND 4.0 license http://creativecommons.org/licenses/by-nc-nd/4.0/,which permits distribution and reproduction for noncommercial purposes, provided the author and source are cited

\section{General rights}

Copyright for the publications made accessible via the Queen's University Belfast Research Portal is retained by the author(s) and / or other copyright owners and it is a condition of accessing these publications that users recognise and abide by the legal requirements associated with these rights.

Take down policy

The Research Portal is Queen's institutional repository that provides access to Queen's research output. Every effort has been made to ensure that content in the Research Portal does not infringe any person's rights, or applicable UK laws. If you discover content in the Research Portal that you believe breaches copyright or violates any law, please contact openaccess@qub.ac.uk. 

hormones are translationally regulated

Anna L. Gillespie ${ }^{1}$, Xiaobei Pan ${ }^{1}$, Anna Marco-Ramell ${ }^{2}$ Caroline Meharg ${ }^{1}$ and Brian D. Green ${ }^{1^{*}}$

$4{ }^{1}$ Institute for Global Food Security (IGFS), Queen's University Belfast, United Kingdom

$5 \quad{ }^{2}$ Biomarkers and Nutrimetabolomics group, University of Barcelona

6

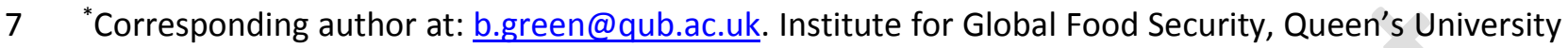
8 Belfast, Stranmillis Road, Belfast, Northern Ireland BT9 6AG, United Kingdom. Tel.: +44 (0)28 9097 96541.

10

Keywords: STC-1, GIP, GLP-1, gut hormones, HCA, gene translation, pGIP/Neo

12

13 Abbrievations: Cholecystokinin (CCK); high content analysis (HCA); glucose-dependent insulinotropic 14 peptide (GIP); glucagon-like peptide-1 (GLP-1); glucagon-like peptide- 2 (GLP-2); peptide YY (PYY); 15 prohormone convertase 3 (PC3); type 2 diabetes mellitus (T2DM); ubiquitin-conjugating enzyme 16 E2D2 (E2D2). 
Abstract

STC-1 is a heterogeneous plurihormonal cell line producing several prominent gut peptide hormones. pGIP/Neo is a genetically selected sub-clone of STC-1 with augmented levels of glucose-dependent insulinotropic peptide (GIP). Morphometric parameters, hormone concentrations, mRNA transcripts, hormone immunocytochemistry and nutrient utilisation/production of these two cell lines were compared. Proglucagon-derived peptides (Glucagon-like peptide-1 (GLP-1) and - 2(GLP-2)) were lower in sub-clone cells than progenitor cells. High Content Analysis found altered intracellular GLP-1, GIP, cholecystokinin (CCK) and peptide YY (PYY) levels and differing hormone co-localisation. The proportion pGIP/Neo cells containing GIP immunoreactivity (82\%) was greater than STC-1 (65\%), as were the proportion with 'GIP only', 'GLP-1 + GIP' or 'GIP + PYY' immunoreactivity. Most surprisingly mRNA transcripts of the proglucagon and GIP genes were inversely correlated to the levels of their translated peptides. This strongly suggests that proglucagon and GIP are encoded on 'translationally regulated genes' - a characteristic possessed by other endocrine hormones. Metabolomic profiling revealed differences in cellular nutrient utilisation/production and that under normal culture conditions both cell lines exhibit signs of overflow metabolism. These studies provide an insight into the metabolism and properties of these valuable cells, suggesting for the first time that incretin hormone genes are translationally regulated. 


\section{Introduction}

Enteroendocrine cells are the most abundant endocrine cell in the human body (Ahlman \& Nilsson, 2001). They are specialised gastrointestinal cells secreting hormones into either, the circulation (for systemic actions), the extracellular space (for paracrine signalling), or to the enteric nervous system (for stimulation of nerve endings). There are the ' $L$ ' cells, originally classified on basis of enteroglucagon immunoreactivity. These are commonly distinguished from the ' $\mathrm{K}$ ' cells which produce the incretin hormone, glucose-dependent insulinotropic peptide (GIP), and the 'I' cells which produce cholecystokinin (CCK). The term enteroglucagon encompasses the intestinal proglucagon-derived peptides: glucagon-like peptide (GLP)-1 (the other incretin hormone), the gut growth factor GLP-2, and the anorexigenic hormone oxyntomodulin (Baggio \& Drucker, 2007). The ' $\mathrm{K}$ ' cells tend to predominate in the duodenum and decrease in number toward the distal end of the small intestine. ' $\mathrm{L}$ ' cells predominate in the ileum and colon and decrease in number toward the proximal end of the small intestine (Mortensen, Petersen, \& Ørskov, 2000). However, this simplistic view is complicated by the fact that many enteroendocrine cells simultaneously express more than one hormone. For example, GLP-1 occurs in subsets of duodenal ' $\mathrm{K}$ ' cells and also immunoreactive GIP occurs in subpopulations of proximal 'L' cells (Mortensen, Petersen, \& Ørskov, 2000; Theodorakis et al. 2006). Ileal and colonic 'L' cells are well known to also express PYY or CCK (Roth, Kim \& Gordon, 1992). The cellular colocalisation of hormones is supported by studies examining and manipulating hormone profiles in vivo. For example, the targeted ablation of proglucagon-expressing cells with diphtheriatoxin also leads to substantial losses in the number of PYY-, GIP- and CCK-positive cells (Egerod et al. 2012). Similar targeting of GIP-expressing cells reduces pro-CCK but not proglucagon mRNA transcripts in the duodenum, with a trend toward lower CCK levels in the remaining intestine (Althage et al. 2008). Duodenal jejunum by-pass surgery in rats (which increases the levels of undigested nutrients arriving in the distal gut) increases the population of cells co-expressing GIP and GLP-1 in the jejunum (Speck, et al. 2011). Enteroendocrine cells therefore appear to be flexible, and it has been suggested that the ' $\mathrm{L}$ ', ' $\mathrm{K}$ ' and ' $\mathrm{I}$ ' cells of the small intestine consist of a single cell type which exhibits a hormonal spectrum which is affected by its location within the gastrointestinal tract but also its exposure to dietary nutrients (Habib et al. 2012).

Within type 2 diabetes mellitus (T2DM) research there is considerable interest in GLP-1, GIP, CCK, PYY and other enteroendocrine hormones. GLP-1 receptor agonists and inhibitors preventing GLP-1 degradation, for instance, are currently used in the clinic to treat patients with T2DM (Green \& Flatt, 2007). There is a demand for robust enteroendocrine cell models for the routine screening of nutrients and secretagogues (McCarthy et al. 2015). Established cell lines used for this purpose include: GLUtag 
- derived from an intestinal endocrine tumour arising in the large bowel in proglucagon-simian virus 40 large T antigen transgenic mice (Brubaker et al., 1998); NCl-H716 - a human cell line derived from a poorly differentiated adenocarcinoma of the caecum (De Bruine et al., 1992), and STC-1 which is a neuroendocrine cell line derived from tumours arising in transgenic mice (McCarthy et al. 2015).

Several years ago there was an interest in genetically engineering enteroendocrine cells to produce preproinsulin (Cheung et al., 2000; Ramshur, Rull \& Wice., 2002) as a novel therapy for type 1 diabetes. This attempted to exploit similarities between enteroendocrine ' $\mathrm{K}$ ' cells and pancreatic $\beta$-cells i.e. mechanisms regulating hormone production/secretion, the timing of hormone release, and the presence of prohormone convertases ( 2 and 3) for posttranslational processing (Ramshur, Rull \& Wice, 2002). The initial step before insertion of the insulin gene, involved initially selecting those cells with a 'K' cell phenotype i.e. those with an active GIP promoter. Ramshur, Rull \& Wice (2002) sub-cloned the STC-1 cell line to produce the pGIP/Neo cell line. This involved transfection with a plasmid (pGIP/Neo) encoding neomycin phosphotransferase driven by the GIP promoter, with only those cells with an active GIP promoter surviving genetic selection (Ramshur, Rull \& Wice, 2002). pGIP/Neo cells therefore provide a unique opportunity to probe STC-1 which natively is a heterogeneous and plurihormonal population of cells (Brubaker et al., 2003). Quantitative studies employing a specific GIP ELISA demonstrate that pGIP/Neo cells produce and secrete 3 to 6 times more GIP whilst retaining an ability to synthesize and secrete CCK and PYY (Hand et al. 2012). However, further characterisation studies are needed to assess this potential model for GIP secretion. It has not yet been established if pGIP/Neo produces proglucagon-derived peptides or retains GLP-1 secretory activity. This study undertook the first detailed comparison of STC-1 and pGIP/Neo cells. Detailed characterisation studies involved not only assessing differences in the abundance/secretion of proglucagon peptides (GLP-1 and GLP-2), but also the application of high content analysis (HCA) to examine on a cell-by-cell basis how intracellular GLP-1, GIP, CCK and PYY (and their co-localisation) are affected. HCA was also employed to examine morphometric differences (nuclei size/shape/staining intensity) between progenitor STC-1 cells and pGIP/Neo cells. Quantitative measures of gene expression (transcript numbers) for each hormone, as well as, Prohormone convertase 3 (PC3) and Ubiquitin-conjugating enzyme E2D2 were undertaken. Finally, biochemical profiling of cell-cultured media assessed the similarities and differences in their nutrient utilisation/production. The findings bring forward new information relating to the metabolism of enteroendocrine cells and the regulation of incretin hormone biosynthesis.

\section{Materials and Methods}

\section{1. Materials}


Antibodies anti-Gastric Inhibitory Polypeptide (GIP) (Alexa Fluor 647), anti-Cholecystokinin (CCK) (Alexa Fluor 555) and anti-Peptide YY antibody (Cy3) were purchased from antibodies-online GmbH (Aachen, Germany) and the Glucagon-like Peptide-1 (GLP-1) antibody (FITC) Biorbyt (Cambridge, UK). PBS tablets, Triton -X 100 10\% solution and Formalin were purchased from Sigma (Dorset, UK).

\subsection{Cell culture}

STC-1 and pGIP/Neo cell lines were received as a gift from Dr. B. Wise (Washington University of St. Louis) with permission from Dr. D. Hanahan (Swiss Institute for Experimental Cancer Research, Lausanne, Switzerland). STC-1 cells were cultured in Dulbecco's Modified Eagle Medium (DMEM) containing high glucose, $4.5 \mathrm{~g} / \mathrm{L}$, with L-glutamine, and without sodium pyruvate (Gibco, Paisley, UK). The medium was supplemented with $17.5 \%$ foetal bovine serum (FBS), $100 \mathrm{U} / \mathrm{mL}$ penicillin and 100 $\mathrm{mg} / \mathrm{L}$ streptomycin. pGIP/Neo STC-1 cells were also cultured in DMEM containing high glucose, 4.5 $\mathrm{g} / \mathrm{L}$, with L-glutamine, and without sodium pyruvate, however the medium contained $10 \%$ FBS and geneticin (G418, $400 \mathrm{ug} / \mathrm{mL}$, Sigma, Poole, Dorset, UK). Both cell medium were incubated in a $5 \% \mathrm{CO}_{2}$ humidified atmosphere at $37^{\circ} \mathrm{C}$. Cells underwent passage upon reaching $80-90 \%$ confluence and were used between passage numbers 15-50.

\subsection{Media accumulation and intracellular content of GLP-1 and GLP-2}

STC-1 and pGIP/Neo cell lines were seeded in 24-well plates at a density of $2 \times 10^{5} /$ well and incubated in a $5 \% \mathrm{CO}_{2}$ humidified atmosphere at $37^{\circ} \mathrm{C}$ overnight. Media was removed and $1 \mathrm{ml}$ of fresh media added to each well and cells were incubated as above for $72 \mathrm{~h}$ upon which the media was collected, centrifuged to remove cellular debris and stored at $-80^{\circ} \mathrm{C}$ prior to ELISA analysis.

To assess the cellular hormone content acid/Ethanol ( $1.5 \% \mathrm{v} / \mathrm{v} \mathrm{HCl}, 75 \% \mathrm{v} / \mathrm{v}$ ethanol, $23.5 \% \mathrm{v} / \mathrm{v} \mathrm{H}_{2} \mathrm{O}$ ) was added and incubated overnight at $4^{\circ} \mathrm{C}$. The incubation solution was removed and centrifuged (900g, $5 \mathrm{~min}$ ) to remove cellular debris. The supernatant was collected and the ethanol evaporated off using a Speedvac sample concentrator (Genevac, Ipswich, UK). Samples were reconstituted in PBST $0.1 \% \mathrm{BSA}$ and stored at $-80^{\circ} \mathrm{C}$ prior to ELISA measurement.

\subsection{Determination of GLP-1 and GLP-2 using ELISA}

GLP-1 and GLP-2 (Total) concentrations were measured using ELISA kits purchased from Merck Millipore (Hertfordshire, UK). The assays were performed in accordance with the manufacturer's instructions. The plates were read at $450 \mathrm{~nm}$ and $590 \mathrm{~nm}$ in a plate reader (Tecan, Safire ${ }^{2}$ ). 
Antibodies were prepared in 1\% BSA in phosphate buffered saline with tween (PBST) immediately prior to adding to cells and protected from the light after preparation. Cells were seeded into 96-well plates $\left(5 \times 10^{4}\right.$ per well) and cultured overnight at $37^{\circ} \mathrm{C}$ in a humidified atmosphere of $5 \% \mathrm{CO}_{2}$. Media was removed and cells fixed with $10 \%$ formalin for $10 \mathrm{~min}$ at room temperature. Cells were washed (x4) with PBS and permeabilisation solution added and incubated for $30 \mathrm{~min}$ at room temperature. Again, cells were washed $(x 4)$ with PBS before blocking solution $(0.3 \mathrm{M}$ glycine $+10 \%$ goat serum in $1 \%$ BSA in PBST (PBS + 0.01\% Tween 20) was added for a further $1 \mathrm{~h}$. The blocking solution was removed and the GLP-1, GIP, CCK or PYY antibody was added (1:200 dilution) and allowed to incubate overnight. Supernatant was removed and cells were washed with PBS ( 3 times $\times 5 \mathrm{~min}$ ) in the dark, after which Hoechst staining solution (Thermo Scientific, Hampstead, UK) was added for $10 \mathrm{~min}$. Cells were washed with PBS (x1) and PBS added to each well and the plate was sealed prior to reading using the ArrayScan ${ }^{\circledR}$ HCS Reader (Thermo, Loughborough, UK). The plate was evaluated at absorbance 350$461 \mathrm{~nm}$ and $485-520 \mathrm{~nm}$ for Hoechst dye and antibody fluorescence, respectively. Typical micrographs obtained from the ArrayScan ${ }^{\circledR}$ system can be found in Figure 1.

\subsubsection{HCA software parameters}

We determined the percentage of cells with immunoreactivity to GLP-1, GIP, PYY or CCK by application of the HCS Studio Cell Analysis Software (Thermo Scientific, Hampstead, UK). Parameters from the results database each individual cell were queried by applying the appropriate conditions e.g. GLP-1 only, AND NOT GIP, NOT CCK and NOT PYY (to find cells immunoreactive to GLP-1 ONLY). This was carried out in a similar manner for each hormone and combination of hormones. The percentage of immunoreactive cells was then calculated for each well. For the in-depth analysis of GIP immunoreactive cells, reference values were set and values that fell above the lowest quartile but below the highest quartile were determined to be 'with-in range'. Values with immunoreactivity in the highest quartile were classified as 'High immunoreactivity', whereas immunoreactivity values in the lowest quartile were classified as 'low immunoreactivity'.

Cells classified as 'low immunoreactivity' were analysed manually to determine the percentage of these cells with 'zero immunoreactivity'.

\subsection{Gene expression}

169 Cells were seeded at a density of $1 \times 10^{6}$ per well for each cell line and incubated at $5 \% \mathrm{CO}_{2}$ humidified 170 atmosphere at $37^{\circ} \mathrm{C}$ overnight. RNA was extracted using the High Pure Isolation Kit Version 12 (Roche Diagnostics, West Sussex, UK) performed in accordance with the manufacturer's instructions. RNA was quantified on the Nanodrop 8000 and $1 \mu \mathrm{g}$ was taken forward for cDNA synthesis using the 
173 Transcriptor First Strand cDNA Synthesis Kit (Roche Diagnostics, West Sussex, UK). A total reaction 174 volume of $20 \mu \mathrm{L}$ contained $5 \mu \mathrm{L}$ of cDNA ( $25 \mathrm{ng}$ ), $1 \mu \mathrm{L}$ of each forward and reverse primer ( $300 \mathrm{nM}$ ), 3 $175 \mu \mathrm{L}$ of nuclease-free water (NFW) and $10 \mu \mathrm{L}$ of Mastermix Sybr Green (PrimerDesign, Southampton, 176 UK). Primers and conditions for each gene were: Proglucagon: 5'-GGCACATTCACCAGCGACTAC-'3 and 177 5'-CAATGGCGACTTCTTCTGGG-'3 and conditions were $95^{\circ} \mathrm{C}$ for $10 \mathrm{~min}$, then 40 cycles of $95^{\circ} \mathrm{C}$ for $15 \mathrm{~s}$, $17860^{\circ} \mathrm{C}$ for $30 \mathrm{~s}$ and $72^{\circ} \mathrm{C}$ for $30 \mathrm{~s}$. GIP (designed and provided by PrimerDesign Ltd.): 5'179 GGACTGGACTCTGACCTTAGC-'3 and 5'-GGCTTTATTGGTTTGGTTCTCTC-'3 and conditions were $95^{\circ} \mathrm{C}$ for $18010 \mathrm{~min}$, then 50 cycles of $95^{\circ} \mathrm{C}$ for $15 \mathrm{~s}$ and $60^{\circ} \mathrm{C}$ for $60 \mathrm{~s}$. PYY: $5^{\prime}$-GGACGCCTACCCTGCCAAACCA- 3 and 5'-AGTGCCCTCTTCTTAAACCAAACA-' 3 and conditions were $95^{\circ} \mathrm{C}$ for $10 \mathrm{~min}$, followed by 40 cycles of $95^{\circ} \mathrm{C}$ for $15 \mathrm{~s}, 63^{\circ} \mathrm{C}$ for $30 \mathrm{~s}$ and $72^{\circ} \mathrm{C}$ for $30 \mathrm{~s}$. CCK: $5^{\prime}-C_{G C G T T T T A C G G G A A G T C A-'} 3$ and $5^{\prime}-$ TCAAGTGTAGCAGGGCTTTGG-' 3 and conditions were $95^{\circ} \mathrm{C}$ for $10 \mathrm{~min}$, followed by 40 cycles of $95^{\circ} \mathrm{C}$ for $15 \mathrm{~s}, 61^{\circ} \mathrm{C}$ for $30 \mathrm{~s}$ and $72^{\circ} \mathrm{C}$ for $30 \mathrm{~s}$. PC3: 5'-CGCTGACCTGCACAATGACT-'3 and 5'CAGACAACCAGGTGCTGCAT-' 3 and conditions were $95^{\circ} \mathrm{C}$ for $10 \mathrm{~min}$, followed by 40 cycles of $95^{\circ} \mathrm{C}$ for $15 \mathrm{~s}, 61^{\circ} \mathrm{C}$ for $30 \mathrm{~s}$ and $72^{\circ} \mathrm{C}$ for $30 \mathrm{~s}$. E2D2: 5'-CATAAAGAGTAGCTGACCGAACCT-'3 and 5'GCTGGCCTGGCTTACATTTAG and conditions were $95^{\circ} \mathrm{C}$ for $10 \mathrm{~min}$, followed by 40 cycles of $95^{\circ} \mathrm{C}$ for $15 \mathrm{~s}, 61^{\circ} \mathrm{C}$ for $30 \mathrm{~s}$ and $72^{\circ} \mathrm{C}$ for $30 \mathrm{~s}$. 18s: 5'-CTTAGAGGGACAAGTGGCG-'3 and 5'CGCTGAGCCAGTCAGTGTA-' 3 and conditions were $95^{\circ} \mathrm{C}$ for $10 \mathrm{~min}$, followed by 45 cycles of $95^{\circ} \mathrm{C}$ for $10 \mathrm{~s}, 59^{\circ} \mathrm{C}$ for $10 \mathrm{~s}$ and $72^{\circ} \mathrm{C}$ for $25 \mathrm{~s}$. The efficiency of each primer was between $95-105 \%$ efficiency. Specificity of the primers was assessed by melt-curve analysis and gel electrophoresis of the PCR product. Six individual wells from two different cell incubations were run in triplicate for each cell line. The genes were quantified by the principles of absolute quantification. A standard curve for each gene was generated by purifying the relevant PCR product using QIAquick PCR Purification Kit (Qiagen, Manchester, UK) and quantified on the Nanodrop 8000. The following equations used to determine the number of molecules present: $\mathrm{Xg} / \mu \mathrm{L}$ DNA / [plasmid length in base pairs or length of PCR products $\times 660]) \times 6.022 \times 10^{23}=Y$ molecules $/ \mu \mathrm{L}$. A standard curve was generated by dilution of the purified PCR product in nuclease-free water to obtain $2.0 \times 10^{8}$ molecules $/ \mu \mathrm{L}$ and 10 -fold serial dilutions carried out to obtain standards ranging from $2.0 \times 10^{7}$ to $2.0 \times 10^{0}$ molecules $/ \mu \mathrm{L}$. Standards were run along with the samples from each cell line and the number of molecules in each sample was determined. The 18s gene was also quantified in the same manner and used as a reference gene. qRT-PCR experiments were carried out using the Eppendorf MasterCycler Realplex (Rotselaar, Belgium).

\subsection{Metabolomics}


Absolute IDQ p180 Kit (BIOCRATES Life sciences, Innsbruck, Austria), which could simultaneously quantify 187 metabolites including amino acids, acylcarnitines, phospho- and sphingolipids, hexose (glucose), and biogenic amines. Briefly, $10 \mu \mathrm{L}$ of culture medium was applied to a 96-well plate containing isotopic internal standards. Amino acids and biogenic amines were derivatized using phenylisothiocyanate (PITC) before analysis and extracted with $5 \mathrm{mmol} / \mathrm{l}$ ammonium acetate in methanol. Amino acids and biogenic amines were analysed by UPLC-MS in the multiple reaction monitoring (MRM) mode. The concentrations of metabolites were expressed as $\mu \mathrm{mol} / \mathrm{L}$.

\subsection{Statistical Analysis}

Results were expressed as means \pm SEM. Data were compared using the unpaired Student's $t$-test. Groups were considered to be significantly different if $p<0.05\left({ }^{*} P \leq 0.05 ;{ }^{* *} P \leq 0.01 ;{ }^{* *} P \leq 0.001\right)$.

\section{Results}

\subsection{Media accumulation and cellular content of GLP-1 and GLP-2 in cell lines}

Quantitative measurements of total GLP-1 found that STC-1 progenitor cells accumulated significantly more GLP-1 in the media than pGIP/Neo cells (72h; 1.7-fold; P $\leq 0.01$ ). Total cellular GLP-1 content was also significantly greater in STC-1 cells than pGIP/Neo cells (2.5-fold; P $\leq 0.05$ ) (Figure $2 A$ ). GLP-2, the other major preproglucagon product exhibited a similar trend. The progenitor STC-1 cell line displayed greater GLP-2 media accumulation (72h; 2.4-fold; P $\leq 0.001$ ) and greater cellular GLP-2 content (2.5fold, $P \leq 0.001$ ) than the $p G I P / N e o$ cell line (Figure $2 B$ ).

\subsection{Morphometric differences between STC-1 and pGIP/Neo cell lines}

HCA detected modest but significant morphometric differences between STC-1 and pGIP/Neo cell lines in terms of nuclei size, nuclei shape, and intensity nuclei (Hoechst) staining. All parameters were significantly greater in $\mathrm{pGIP/Neo}$ cells (Nuclei size: 1.02 -fold, $P \leq 0.01$, shape: 1.003 -fold, $P \leq 0.05$; fluorescence intensity: 1.1-fold, $\mathrm{P} \leq 0.001$, Figure 3).

\subsection{GLP-1, GIP, PYY and CCK immunoreactivity in STC-1 and pGIP/Neo cell lines}

GLP-1 immunoreactivity was significantly greater in the STC-1 cell line (1.7-fold; $P \leq 0.001)$ (Figure 4A) whereas GIP immunoreactivity was greatest in the pGIP/Neo cell line (1.6-fold; $P \leq 0.001$ ) (Figure 4B). There appeared to be a trend of increased PYY (1.4-fold) (Figure 4C) and CCK (1.1-fold) (Figure 4D) levels in the pGIP/Neo cell line but neither of these were significantly different.

\subsection{Gene transcripts levels in STC-1 and pGIP/Neo cell lines}


The levels of gene transcripts for hormones differed between the cell lines. The mRNA copy number for the proglucagon gene expression (4.1-fold; $\mathrm{P} \leq 0.001$; Figure $5 \mathrm{~A}$ ) and the PYY gene (5.3-fold; $\mathrm{P} \leq 0.001$; Figure $5 \mathrm{C}$ ) were significantly higher in the $\mathrm{pGIP/Neo}$ cell line than the STC-1 cell line. Contrastingly, the mRNA copy number for the GIP gene (47.2-fold; P $\leq 0.001$; Figure $5 B$ ) and the CCK gene (2.7-fold; $P \leq 0.001$; Figure 5D) was significantly higher in the STC-1 cell line than the $p G I P / N e o$ cell line. The levels of gene transcripts for proteins involved in posttranslational processing also differed between the cell lines. E2D2 (a ubiquitin-conjugating enzyme) and the Prohormone Convertase 3 gene (PC3) had higher mRNA copy numbers in the pGIP/neo cell line, increased by 1.8fold and 1.7-fold ( $P \leq 0.01$; Figure 5E \& 5F), respectively.

\subsection{Hormone immunoreactivity profiles of STC-1 and pGIP/Neo cells}

The percentage (\%) of cells classified as 'GLP-1 only', 'PYY only' or 'CCK only' did not significantly differ between STC-1 and pGIP/Neo cell lines (Figure 6A \& 6C). In contrast, the $\%$ of cells classified with 'GIP only' immunoreactivity was significantly higher in the pGIP/Neo cell line (3.5-fold; P $\leq 0.05$ ). Similarly, the $\%$ of cells which co-produced GLP-1+GIP, and GIP+PYY was significantly higher (2.5-fold ( $\leq 0.01)$ and 1.3-fold ( $P \leq 0.05)$, respectively; Figure $6 \mathrm{~A}$ ) but not for GIP+CCK (Figure $6 \mathrm{C}$ ). There were no significant differences in the \% of STC-1 and pGIP/Neo cells co-producing GLP-1+PYY (Figure 6A), however with pGIP/Neo cells there were significantly more GLP-1+CCK co-producing cells (1.8-fold; $\mathrm{P} \leq 0.01$; Figure $6 \mathrm{C}$ ). The $\%$ of cells with no immunoreactivity for the hormones tested ('Undefined') did not differ between the cell lines either when they were co-stained for PYY or co-stained for CCK.

\subsection{Differences in GIP immunoreactivity between STC-1 and pGIP/Neo cell lines}

The increased immunoreactivity of the pGIP/Neo cell line was probed in more detail by examining overall proportion of cells with low, within range and high GIP immunoreactivity. The \% of cells with 'GIP within range' immunoreactivity did not significantly differ between the STC-1 and pGIP/Neo cell lines (Figure 7A). However there were significantly fewer pGIP/Neo cells with 'Low GIP immunoreactivity' (1.6-fold; $\mathrm{P} \leq 0.001$; Figure $7 \mathrm{~A}$ ), and at the same time there were significantly more cells of 'High GIP immunoreactivity' (2.1-fold, $\mathrm{P} \leq 0.01)$. Of the cells classified with 'Low GIP immunoreactivity' $56-70 \%$ of these contained no GIP immunoreactivity at all, but did not significantly differ between STC-1 and pGIP/Neo cell lines (Figure 7B). Overall, approximately $65 \%$ of STC-1 cells and $82 \%$ of $\mathrm{pGIP} /$ Neo had GIP immunoreactivity $(\mathrm{P} \leq 0.01)$.

\subsection{LC-MS metabolite profiling of cultured media from STC-1 and pGIP/Neo cells}

For both the STC-1 and pGIP/Neo cells the culture media levels of 187 metabolites were measured before and after $72 \mathrm{~h}$ of culturing. Of the 187 metabolites only 30 were found at measurable levels in 
media. The levels of phenylalanine, threonine, ADMA, creatinine, kynurenine, Met-SO and SDMA did not differ before and after culture in either cell line. The metabolite which most dramatically changed following the period of culture was Pro which increased by $724 \%$ ( $P \leq 0.001$; Supplementary Table 1 ) in STC-1 cells and by $2376 \%(P \leq 0.01)$ in pGIP/Neo cells. Both cell lines utilised glucose in their respective media to a similar extent (60-66\%; $\mathrm{P} \leq 0.001$ ). Propionylcarnitine decreased $46 \%$ ( $\mathrm{P} \leq 0.001$ ) in STC-1 cells and decreased $72 \%(P \leq 0.01)$ in $p G I P / N e o$ cells. The total amount of amino acids or essential amino acids utilised during the culture period did not significantly differ for either STC-1 cells or pGIP/Neo cells. However, significant utilisation of the branched chain amino acids (i.e. leucine, isoleucine and valine) was evident and a number of individual amino acids were significantly affected. Glutamine and lysine decreased by $44 \%$ and $43 \%$ respectively ( $P \leq 0.01$ ) in STC- 1 cells, and by $24 \%$ and $32 \%$ respectively $(P \leq 0.01)$ in pGIP/Neo cells. In contrast the levels of serine increased by $14 \%(P \leq 0.05)$ and $19 \%(P \leq 0.05)$ in STC-1 and pGIP/Neo cells, respectively. Alanine also increased in cultured media from both cell lines but with STC-1 cells the increase was very modest (10\%; P $\leq 0.05)$ compared with pGIP/Neo cells (116\%; $\mathrm{P} \leq 0.001)$. A number of other differences in cultured STC-1 and pGIP/Neo media were evident. Taurine increased by $105 \%$ after STC-1 culture $(P \leq 0.001)$ but decreased by $56 \%$ after pGIP/Neo culture $(P \leq 0.05)$. Arginine and glutamic acid levels were unaffected by STC-1 culture, however, after pGIP/Neo culture arginine was decreased by $26 \%(P \leq 0.001)$, and glutamic acid was increased by $76 \%$ in the pGIP/Neo media $(P \leq 0.05)$. On the other hand ornithine and Alpha-AAA were decreased $58 \%(P \leq$ $0.001)$ and $29 \%(P \leq 0.05)$ respectively after STC-1 culture but neither were affected by $p G I P / N e o$ culture.

\section{Discussion}

pGIP/Neo cells were originally developed by insertion of an expression vector containing nucleotides -1153 to +7 of the rat GIP promoter linked to the neomycin phosphotransferase gene into STC-1 cells (Ramshur, Rull \& Wice 2002). Preferential selection of cells with an active GIP promoter using geneticin resulted in the pGIP/Neo sub-clone cell line. These are the first in-depth characterisation studies of pGIP/Neo. They provide a detailed overview of the various hormone producing cell-types present within these heterogeneous GIP-enriched cells (Hand et al. 2012). The data offer insights into the cellular processes regulating incretin hormone biosynthesis in vitro.

We have demonstrated that the secretion of GIP's sister hormone, GLP-1 is substantially greater in progenitor STC-1 cells than the sub-clone cells. Around $41 \%$ less accumulated in pGIP/Neo cell media over $72 \mathrm{~h}$. This finding was corroborated by quantitative measurement of intracellular GLP1 content as assessed by ELISA. This therefore is the first definitive demonstration that PGIP/Neo STC- 
1 cells shift away from a GLP-1-producing cell phenotype. Using HCA and a GLP-1-specific antibody we were then able to probe relative levels of enteroendocrine hormones and assess their colocalisations within individual cells. Once again this confirmed comparatively higher GLP-1immunoreactivity in progenitor STC-1 cells. Proglucagon gene expression was also assessed in both cell lines, but expression was much greater in pGIP/Neo STC-1 cells, not the progenitor cells. As these findings were entirely contrary to the quantitative peptide measurements and HCA data we rechecked this several times even developing a qRT-PCR measuring the number of proglucagon mRNA transcripts. Following translation the proglucagon is processed to form GLP-1 by prohormone convertase 3 (PC3 or sometimes referred to as PC1). We assessed PC3 gene expression and we quantified another proglucagon-derived peptide GLP-2 to check the discrepancy in proglucagon mRNA and GLP-1 peptides. We found that in a manner similar to GLP-1 both GLP-2 media accumulation and intracellular storage (as assessed quantitatively by ELISA) were significantly greater in the progenitor STC-1 cell line. However, mRNA copy numbers of PC3 were significantly higher in pGIP/Neo STC-1 cells. This demonstrates that there is no direct correlation between the number of proglucagon mRNA copies and the actual abundance of GLP-1 and GLP-2 peptides. Therefore when studying the biology of enteroendocrine cells hormone mRNA and peptide measurements should be viewed as complimentary (Greenbaum et al., 2003). The lack of correlation between the mRNA levels and peptide abundance in progenitor and sub-clone cells is potentially very informative. It has been common practice to consider mRNA abundance as the major determinant of protein abundance, but the many complicated and varied post-translational steps responsible for converting mRNA into protein are frequently overlooked. Emerging evidence suggests that transcript abundance only partially predicts protein abundance. Vogel \& Marcotte (2012) reported that there is only around a $40 \%$ correlation between mRNA and protein abundance, which means that approximately $60 \%$ of variations arise from a combination of post-transcriptional regulation and measurement noise. The strongest contribution evidently comes from protein translation, and it has been proposed that differences could purely be due to energy constraints within the gene expression system (Schwanhausser et al., 2011). Protein synthesis actually consumes more than $90 \%$ of a cell's energy but less than $10 \%$ is consumed by transcription, and so much less energy is required to transcribe mRNA than to translate and process the actual protein. Enteroendocrine cells represent a system which is required to respond quickly to external stimuli and Schwanhausser et al., (2011) found that such systems are characterised by stable mRNA copies and unstable proteins, and classified these as 'translationally regulated genes'. For example, when two ferritin proteins are rapidly upregulated in response to iron, this upregulation is not dependant on the generation of more mRNA but on dynamic translation (Hentze, Muckenthaler \& Andrews, 2004). Similarly, Han et al. (2007) found an increase in 
insulin secretion in a cloned cell line but no significant change in mRNA expression and they suggested this was due to vesicular release rather than transcriptional regulation of the GIP promoter. This adds weight to the argument that translation of the protein is regulated more stringently than transcription. There is some speculation that other homeostatic genes regulate themselves in a similar manner and the proglucagon gene could certainly be categorised as homeostatic. GLP-1 plays an important role in glucose homeostasis and responds rapidly to nutrient ingestion therefore it would seem appropriate that it is regulated at the translational rather than transcriptional level. So it would appear that translational regulation is potentially very important for the biosynthesis of these hormones and it explains the startling discrepancy between the progenitor and sub-clone cell lines examined here. Another important consideration is the incorporation of polysomes. A polysome is a complex containing an mRNA molecule with two or more ribosomes and is indicative of an increase in the rate of translation (Johannes et al., 1999, Mikulits et al., 2000). Greenman et al. (2007) investigated proteins regulated by glucose through changes of their protein synthesis via translational profiling (rather than transcriptional) using microarray analysis of MIN6 cells acutely incubated at either low or high glucose concentrations. A total of 313 transcripts, particularly those associated with metabolism or gene expression were associated with polysomes. Furthermore, it appeared possible for transcripts to be redistributed to heavier polysomes in the presence of a high glucose environment. Interestingly, glucose-induced proinsulin synthesis is mainly achieved by enhancing the translation efficiency of proinsulin mRNA pre-existent on the membrane-bound polysome in pancreatic islets (Itoh \& Okamoto, 1980). Similar studies in enteroendocrine cells regarding incretin hormones have not yet been carried out but given the similarities between GIP and insulin biosynthesis (Ramshur, Rull \& Wice, 2002), it is not unreasonable to suggest a similar mechanism for incretin hormones. In general, it is seems important to remember that mRNAs and proteins are information carriers of the cell. Their degradation or translation can be an in-built timer controlling the persistence of genetic information (Pedraza \& Paulsson, 2008). Sufficient quantities of peptide produced by the cell can trigger negative feedback reducing mRNA transcription which is another reason to explain the lack of correlation in this study.

Indeed, GIP mRNA and protein abundance did not correspond either. In this case the relationship was reversed with pGIP/Neo having significantly fewer mRNA GIP transcripts, yet significantly greater intracellular GIP. Both GLP-1 and GIP are post-translationally processed by PC3. Therefore it appears that the pGIP/Neo expression vector in the sub-clone cells has preferred translation and processing of GIP rather than GLP-1. The greater constitutive GIP producing status of the cells results in reduced mRNA levels of GIP because this is more efficient for the cell. With this in mind, the default position of progenitor STC-1 cells is to favour GLP-1 production; hence the cells generating more GIP mRNA in 
order to ensure adequate supply of GIP should the cells be required to switch production.

371 Furthermore, since the sub-clone cell line has significantly more expression of PC3 gene for both GLP-

3721 and GIP processing this may suggest that this cell line has an enhanced ability to post-translationally process peptides than the STC-1 cell line. In addition, we detected significantly greater gene expression of the ubiquitin-conjugating enzyme E2D2 (E2D2) in pGIP/Neo compared with the STC-1 cell line. Ubiquitin enzymes determine protein turnover, regulation, molecular function and provide a complex regulation of the proteome and the E2 enzymes have been ascribed a role in deciding the 'life or death' of a protein (van Wijk \& Timmers, 2010). At the present time there is no evidence that E2D2 influences the fate of any of the peptides discussed here, but we do note a correlation between PC3 expression, E2D2 expression, and increased GIP production. The caveat here is that only mRNA was measured for PC3 and E2D2 and the corresponding protein levels or enzyme activities have not been assessed.

We observed a trend of higher intracellular PYY and CCK levels in pGIP/Neo compared with STC-1 but this was not statistically significant. However, there were significantly more PYY mRNA transcripts in pGIP/Neo, and in contrast, significantly fewer CCK mRNA transcripts. It has not been established precisely how these prepropeptides are processed to their biologically active forms but prohormone convertases are thought to be involved (Yoon \& Beinfeld, 1997). Once again the differences in PYY/CCK expression did not reflect differences in PYY and CCK immunoreactivity (HCA), but it is entirely possible that these peptide hormones are more tightly regulated at a translational level, rather than at a transcriptional level.

The in-depth cell-by-cell analysis using the HCA also gave an interesting insight into the co-localisations of four enteroendocrine hormones in both of these cell lines. Technical constraints meant that we could not measure all four hormones simultaneously (four-channel fluorescent imaging, but with onechannel reserved for Hoechst nuclear staining). Therefore, hormones were measured in two sets of triplets (i.e. GLP-1, GIP \& PYY and GLP-1, GIP \& CCK) with the two incretins serving as reference points. HCA data clearly verify that the pGIP/Neo STC-1 cell line contains more cells with more GIPimmunoreactivity than the progenitor STC-1 cell line. There were not just increases in cells which were exclusively GIP-immunoreactive but also an increase in the number of cells which were immunoreactive for GLP-1 + GIP, and for GIP + PYY. Overall, the number of cells with GIP immunoreactivity increased by $17 \%$ in the pGIP/Neo cell line. GLP-1 and PYY are both associated with the ' $L$ ' cell phenotype (Schwartz \& Holst, 2010), therefore an increase of either in combination with GIP seems logical. Cells with immunoreactivity for GLP-1 + CCK were also significantly higher in the pGIP/Neo cell line. Roth, Kim \& Gordon (1992) has suggested that the enteroendocrine cell lineage has two branches one of which produces CCK, GLP-1, PYY, and neurotensin. Increased GLP-1 + CCK 
immunoreactivity suggests such a lineage exists within pGIP/Neo. Interestingly, both cell lines are comprised of $20-30 \%$ which are exclusively immunoreactive for PYY or CCK, which is much more than either GLP-1 or GIP only cells. Initially STC-1 cells were employed as a model of native CCK-producing ' $\mathrm{I}$ ' cells and on occasion it has been used to measure GLP-1 secretory activity. Only recently, PYY was discovered to be present in the STC-1 cell line (Geraedts et al. 2009; Hand et al. 2012) but here we report the true extent of PYY abundance. Approximately $56 \%$ of STC- 1 cells, and $67 \%$ of pGIP/Neo STC1 cells produce detectable PYY. Egerod et al. (2012) reported that although CCK is the most abundantly expressed peptide hormone at the RNA level in CCK-eGFP-positive mouse intestinal tissue cells in the duodenum, PYY was expressed to a similar level within these cells. They also found cells co-store these hormones in the gastrointestinal (GI) tract of mice. This work demonstrates that enteroendocrine cells are less heterogeneous than previously thought which is in keeping with the concept of fewer cell types but exhibiting a hormonal spectrum (Habib et al., 2012; Egerod et al. 2012). Importantly, the percentage of cells classified here as 'undefined' could represent cells possessing immunoreactivity for three or more of the hormones.

As mentioned the percentage of cells containing some form of GIP immunoreactivity i.e. including low (minus zero immunoreactivity), within range, or high increased from $65 \%$ in the progenitor cell line to $82 \%$ in pGIP/Neo. The percentage of cells with zero GIP immunoreactivity tended to be lower in pGIP/Neo but was not significant. However, the percentage of pGIP/Neo cells with intense GIP immunoreactivity was significantly increased, and the percentage with low GIP immunoreactivity significantly decreased. This proves the utility of HCA in characterising novel cell lines by showing how the pGIP/Neo population gives rise to more GIP peptide.

One potential limitation of the current study is that the two cell lines have different cell culture medium requirements. The higher serum levels of STC-1 (17.5\% FBS versus 10\% FBS for GIP/Neo) could potentially increase cell growth or cell density, which in turn could increase enteroendocrine hormones levels. Neither our pilot studies ( $72 \mathrm{~h}$ ) nor the High Content Analysis studies $(<24 \mathrm{~h})$ detected any significant differences in the rate of cell proliferation between the two cell lines. Furthermore, it should be mentioned that some hormones i.e. GLP-1 and GLP-2 actually decreased rather than increased. Nonetheless, if future studies could harmonise the cell culture medium used for the two cell lines this would minimise any confounding effect from this.

Metabolomic profiling of media (pre-culture versus cell-cultured) culture assessed nutrient utilisation of the cell lines. Since the composition of the cell culture media differs between cell lines pairwise statistical comparisons were not possible. However, metabolite profiling did reveal a number of 
similarities and differences in the nutrient utilisation/production of cell lines. At first glance the energy requirements of the two cell lines appear broadly similar. Reductions in glucose in the media suggest equivalent levels of glycolytic activity. Furthermore, another key source of cellular energy, glutamine, was utilised to similar extent in both cell lines. A major difference between cell lines was that pGIP/Neo cells had much greater propensity to utilise propionylcarnitine. Propionylcarnitine is a carrier of propionate which enters the Kreb's cycle and contributes to cellular energy (Brevetti et al., 1997).

Both cell lines appeared to produce substantial quantities of proline, which is not surprising given that other cell lines have been reported to produce and release proline into the cell culture medium (Genzel et al. 2004). Proline production apparently results from overflow metabolism of glutamine which ends in excess production of ammonium and the amino acids alanine, proline, ornithine, asparagine, glutamate, serine and glycine (Ljunggren and Häggström, 1992). We observed significant increases in alanine and serine in both cell lines and in pGIP/Neo cell-cultured media glycine was also increased. Closer examination of proline, alanine, serine and glycine suggests that both cell lines, but possibly to a greater extent the pGIP/Neo cell line exhibit signs of overflow metabolism i.e. an incomplete oxidation of an abundant energy source (despite aerobic conditions) resulting in an excretion of organic, often inhibitory end products (Amribt, Niu \& Bogaerts, 2012).

Although neither cell line significantly depleted total essential amino acid levels, the levels of total branched chain amino acids were reduced. There was evidence that a number of other amino acids being utilised by both cell lines including lysine which is important for protein synthesis which is reliant on lysine modifications such as methylation, ubiquitination, sumoylation, neddylation, biotinylation (Sadoul et al., 2008). Taurine was one of the amino acids which significantly altered. In STC-1 cellcultured media it almost doubled in concentration, however, in pGIP/Neo cell-cultured media it approximately halved. The reasons for this differences in taurine levels are not immediately clear.

\section{Conclusion}

In conclusion these studies provide detailed profiling and characterisation of the novel pGIP/Neo cell

464 line. Our data show for the first time that production and secretion of proglucagon peptides (GLP-1 465 and GLP-2) are significantly decreased in pGIP/Neo compared to the progenitor STC-1 cell line. 466 Furthermore, we have provided substantial confirmatory evidence that GIP production is increased in pGIP/Neo cells with a significantly greater percentage of pGIP/Neo cells having high GIP immunoreactivity. However, the most surprising observation was that observed peptide levels were not reflected in the mRNA transcript levels. Despite observing greater GIP production in the pGIP/Neo 
470 cell line, the progenitor STC-1 cells had many more GIP mRNA transcripts. The same discrepancy was

471 found for GLP-1 production and proglucagon transcripts than the sub-clone pGIP/Neo cells. Firstly

472 this exposes the pitfall of interpreting increased transcript levels as leading to increases in incretin

473 peptides but most interestingly it provides the first evidence suggesting that enteroendocrine

474 hormones may be produced on translationally regulated genes. Metabolomic profiling highlighted

475 that in many respects the utilisation and release of many nutrients (including glucose) from STC-1 and

$476 \mathrm{pGIP} / \mathrm{Neo}$ cells do not differ. However, pGIP/Neo cells utilise proportionately more

477 proprionylcarnitine from culture media suggesting altered energy metabolism. Furthermore,

$478 \mathrm{pGIP} /$ Neo cells produce more proline, serine, alanine and glycine which is indicative of overflow

479 metabolism. The pGIP/Neo cell line is a useful tool for investigating GIP secretion and studying

480 changes in the co-localisation of enteroendocrine hormones. Future investigations should further

481 probe the specific processing involved in the production of incretin hormone proteins, as such work

482 could provide targets for diabetes pharmacotherapy.

484 Acknowledgements

485 We gratefully acknowledge PhD Studentship funding provided by the Department of Agriculture and

486 Regional Development (DARD) Northern Ireland and the guidance of Dr Caroline Frizzell for cell

487 culture studies.

488

489 Author Contributions

490 ALG performed the experiments, analysed and interpreted the data and drafted the manuscript. XP

491 performed metabolomic profiling and data analysis, AMR performed cell studies and data analysis,

492 CM designed studies and analysed and interpreted the data, BDG conceived the study, designed the

493 experiments, interpreted the data, and drafted the manuscript. All authors approved the final version

494 of the manuscript to be published. 
496

497

498

499

500

501

502

503

504

505

506

507

508

509

510

511

512

513

514

515

516

517

518

519

Amribt, Z., Niu, H., \& Bogaerts, P. (2012). Macroscopic modelling of overflow metabolism in fed-batch cultures of hybridoma cells. Biochemical Engineering Journal, 70, 196-209.

Baggio, L.L., Drucker, D.J. (2007). Biology of incretins: GLP-1 and GIP. Gastroenterology, 132: 21312157.

Brevetti, G., Fanin, M., De Amicis, V., Carrozzo, R., Di Lello, F., Martone, V.D., \& Angelini, C. (1997). Changes in skeletal muscle histology and metabolism in patients undergoing exercise deconditioning: effect of propionyl-L-carnitine. Muscle Nerve, 20, 1115-1120.

Brubaker, P. L., Izzo, A., \& Rocca, A. S. (2003). Synthesis and secretion of intestinal proglucagonderived peptides by the STC-1 enteroendocrine cell line. Canadian Journal of Diabetes, 27, 141-148.

Brubaker, P. L., Schloos, J., \& Drucker, D. J. (1998). Regulation of glucagon-like peptide-1 synthesis and secretion in the GLUTag enteroendocrine cell line. Endocrinology, 139(10), 4108-4114.

Cheung, A. T. (2000). Glucose-Dependent Insulin Release from Genetically Engineered K Cells. Science, 290 (5498), 1959-1962.

De Bruine, A. P., Dinjens, W. N., Pijls, M. M., vd Linden, E. P., Rousch, M. J., Moerkerk, P. T., de Goeij, A. F. P. M., \& Bosman, F. T. (1992). NCI-H716 cells as a model for endocrine differentiation in colorectal cancer. Virchows Archiv B, 62(1), 311-320.

Egerod, K. L., Engelstoft, M. S., Grunddal, K. V., Nøhr, M. K., Secher, A., Sakata, I., \& Schwartz, T. W. (2012). A major lineage of enteroendocrine cells co-express CCK, secretin, GIP, GLP-1, PYY, and neurotensin but not somatostatin. Endocrinology, 153(12), 5782-5795.

Green, B. D., \& Flatt, P. R. (2007). Incretin hormone mimetics and analogues in diabetes therapeutics. Best Practice \& Research Clinical Endocrinology \& Metabolism, 21(4), 497-516.

Greenman, I. C., Gomez, E., Moore, C. E. J., \& Herbert, T. P. (2007). Distinct glucose-dependent stress responses revealed by translational profiling in pancreatic beta-cells. Journal of Endocrinology, 192(1), 179-187. 

growth and influenza virus production in large-scale microcarrier culture. Vaccine, 22(17-18), 22022208.

Geraedts, M. C. P., Troost, F. J., \& Saris, W. H. M. (2009). Peptide-YY is released by the intestinal cell line STC-1. Journal of Food Science, 74(2), H79-H82.

Hand, K. V., Giblin, L., \& Green, B. D. (2012). Hormone profiling in a novel enteroendocrine cell line pGIP/neo: STC-1. Metabolism, 61(12), 1683-1686.

527

Hentze, M. W., Muckenthaler, M. U., \& Andrews, N. C. (2004). Balancing acts: molecular control of mammalian iron metabolism. Cell, 117, 285-297.

Itoh, N. \& Okamoto, H. (1980). Translational control of proinsulin synthesis by glucose. Nature, 283, 100-102.

Johannes, G., Carter, M.S., Eisen, M.B., Brown, P.O., \& Sarnow, P. (1999). Identification of eukaryotic mRNAs that are translated at reduced cap binding complex elF4F concentrations using a cDNA microarray. Proceedings of the National Academy of Sciences, 96, 13118-13123.

Ljunggren, J., \& Häggström, L. (1992). Glutamine limited fed-batch culture reduces the overflow metabolism of amino acids in myeloma cells. Cytotechnology, 8(1), 45-56.

McCarthy, T., Green, B.D., Calderwood, D., Gillespie, A., Cryan, J. F., \& Giblin, L. (2015). STC-1 cells. In Verhoeckx, K. Cotter, P., López-Expósito, I., Kleiveland, C., Lea, T., Mackie, A., Requena, T., Swiatecka, D., \& Wichers, H. (Eds.), The Impact of Food Bioactives on Health: In Vitro and Ex Vivo Models (pp. 211220). http://doi.org/10.1007/978-3-319-16104-4

Mikulits, W., Pradet-Balade, B., Habermann, B., Beug, H., Garcia-Sanz, J.A., \& Mullner, E.W. (2000). Isolation of translationally controlled mRNAs by differential screening. FASEB Journal, 14, 1641-1652. Porcine Intestine. Annals of the New York Academy of Sciences, 921(1), 469-472. unexpected insights into Gut K-cell function in vivo. Journal of Cellular Physiology, 192(3), 339-350. 
Roth, K. A., Kim, S., \& Gordon, J. I. (1992). Immunocytochemical studies suggest two pathways for enteroendocrine cell differentiation in the colon. The American Journal of Physiology, 263(2 Pt 1), G174-180.

552 Sadoul, K., Boyault, C., Pabion, M., \& Khochbin., S. (2008). Regulation of protein turnover by 553 acetyltransferases and deacetylases. Biochimie, 90, 306-312.

554 Schwanhäusser, B., Busse, D., Li, N., Dittmar, G., Schuchhardt, J., Wolf, J., \& Selbach, M. (2011). Global 555 quantification of mammalian gene expression control. Nature, 473(7347), 337-342.

556 Schwartz, T. W., \& Holst, B. (2010). An enteroendocrine full package solution. Cell Metabolism, 11(6), $557 \quad 445-447$.

558 Speck, M., Cho, Y. M., Asadi, A., Rubino, F., \& Kieffer, T. J. (2011). Duodenal-jejunal bypass protects GK 559 rats from $\beta$-cell loss and aggravation of hyperglycemia and increases enteroendocrine cells 560 coexpressing GIP and GLP-1. American Journal of Physiology - Endocrinology \& Metabolism, 923-932.

561 Theodorakis, M.J., Carlson, O., Michopoulos, S., Doyle, M.E., Juhaszova, M., Petraki, K., \& Egan, J.M.T 562 (2006). Human duodenal enteroendocrine cells: source of both incretin peptides, GLP-1 and GIP. 563 American Journal of Physiology - Endocrinology and Metabolism, 290: E550-E559.

564 van Wijk, S. J. L., \& Timmers, H. T. M. (2010). The family of ubiquitin-conjugating enzymes (E2s): 565 deciding between life and death of proteins. The FASEB Journal, 24(4), 981-993.

566 Vogel, C., \& Marcotte, E. M. (2012). Insights into the regulation of protein abundance from proteomic 567 and transcriptomic analyses. Nature Reviews Genetics, 13(4), 227-232.

568 Yoon, J., \& Beinfeld, M. C. (1997). Prohormone convertase 2 is necessary for the formation of 569 cholecystokinin-22, but not cholecystokinin-8, in RIN5F and STC-1 cells. Endocrinology, 138(9), 36205703623. 
572 Figure 1. A

STC-1 cell line

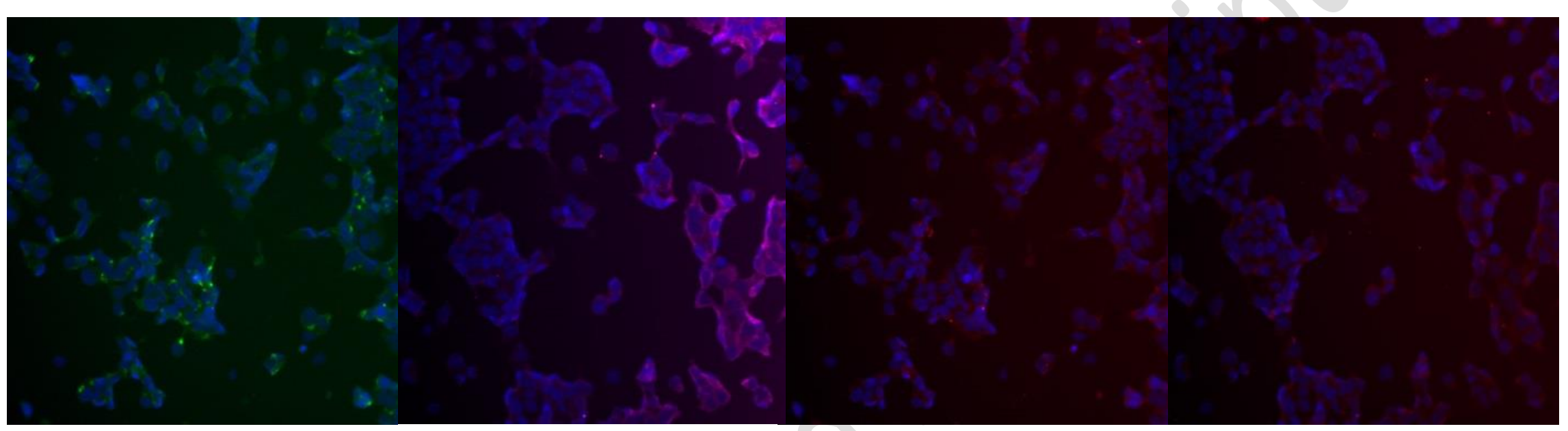

GLP-1

GIP

PYY

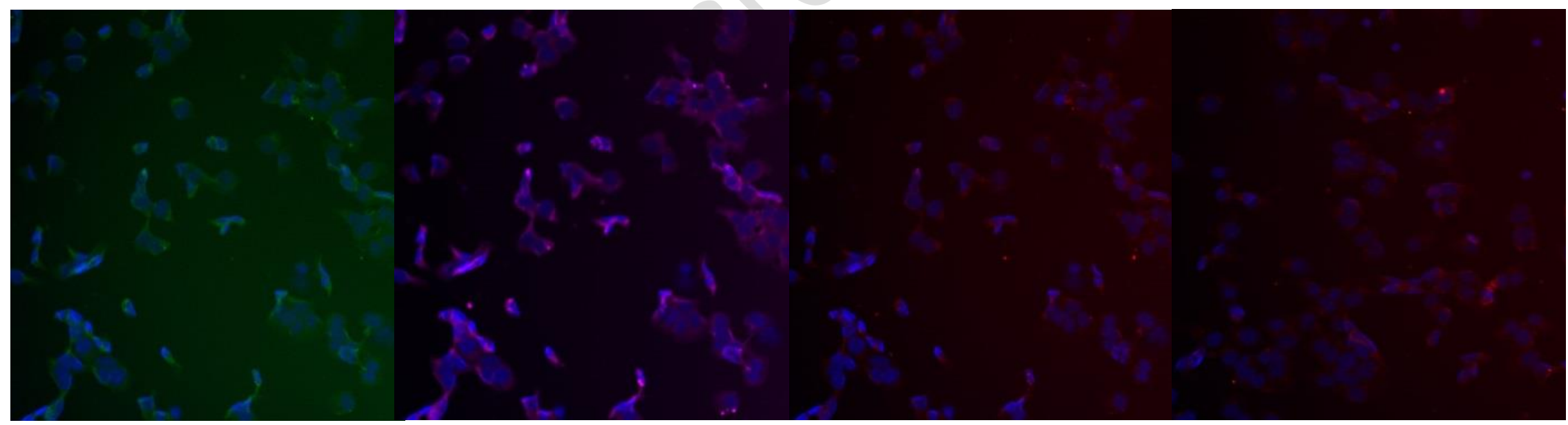



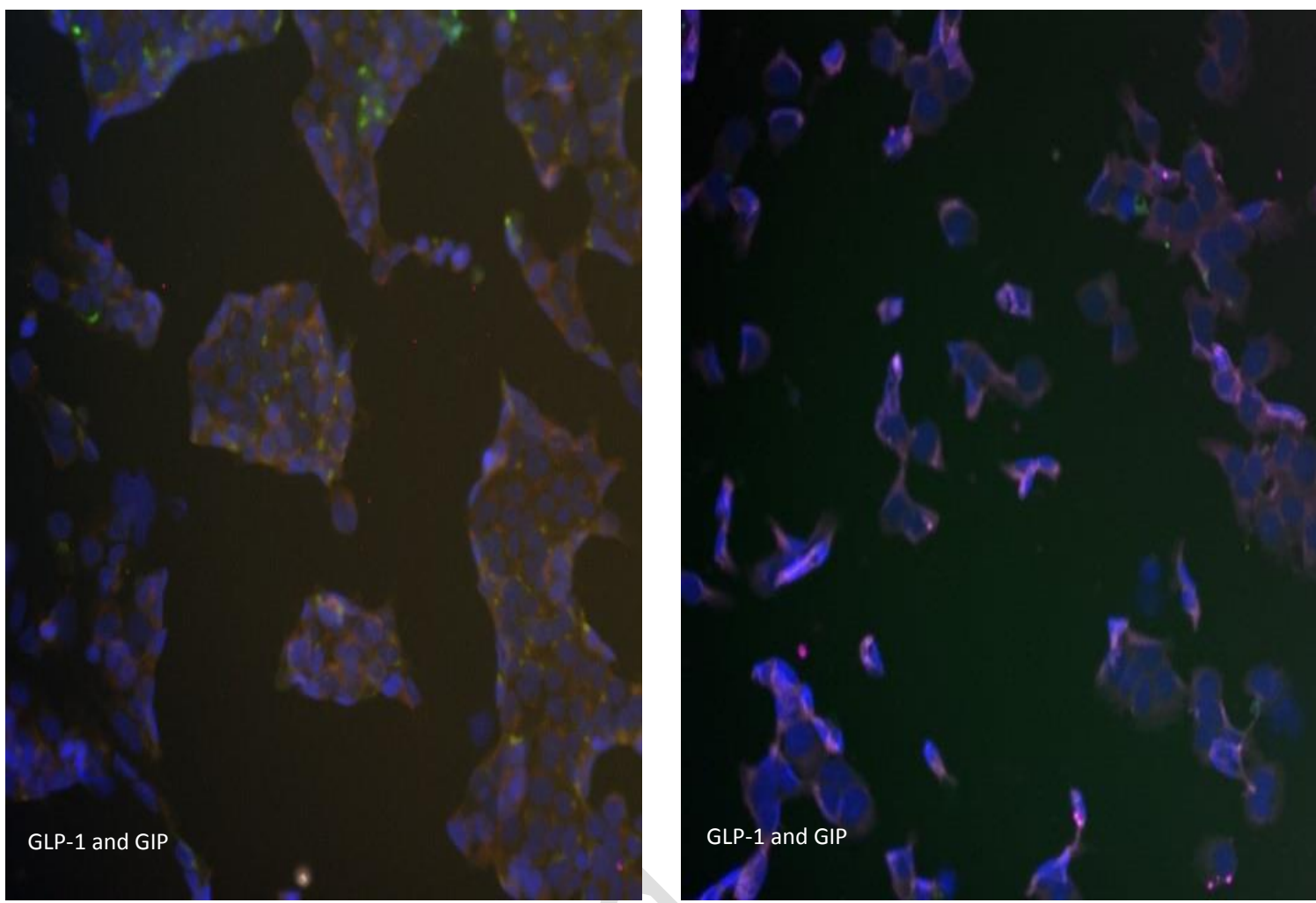

586

587 Figure 1. Typical micrographs from the Arrayscan system. (A) HCA images of GLP-1 (green), GIP

588 (purple), PYY (red) and CCK (red) immunostaining in the two cell lines. GLP-1 immunoreactivity was

589 significantly greater in the STC-1 cell line whereas GIP immunoreactivity was greatest in the

$590 \mathrm{pGIP/Neo} \mathrm{cell} \mathrm{line.} \mathrm{PYY} \mathrm{and} \mathrm{CCK} \mathrm{immunoreactivity} \mathrm{overall} \mathrm{did} \mathrm{not} \mathrm{significantly} \mathrm{differ} \mathrm{between} \mathrm{cell}$

591 lines. (B) Merged images of GLP-1 (green) and GIP (purple) in the cell lines. Note the intensity of the

592 GLP-1 (green) in the STC-1 cell line co-stain image compared with the pGIP/Neo cell line. The

$593 \mathrm{pGIP/Neo}$ cell line had greater intensity of GIP (purple).

594

595

596 
A

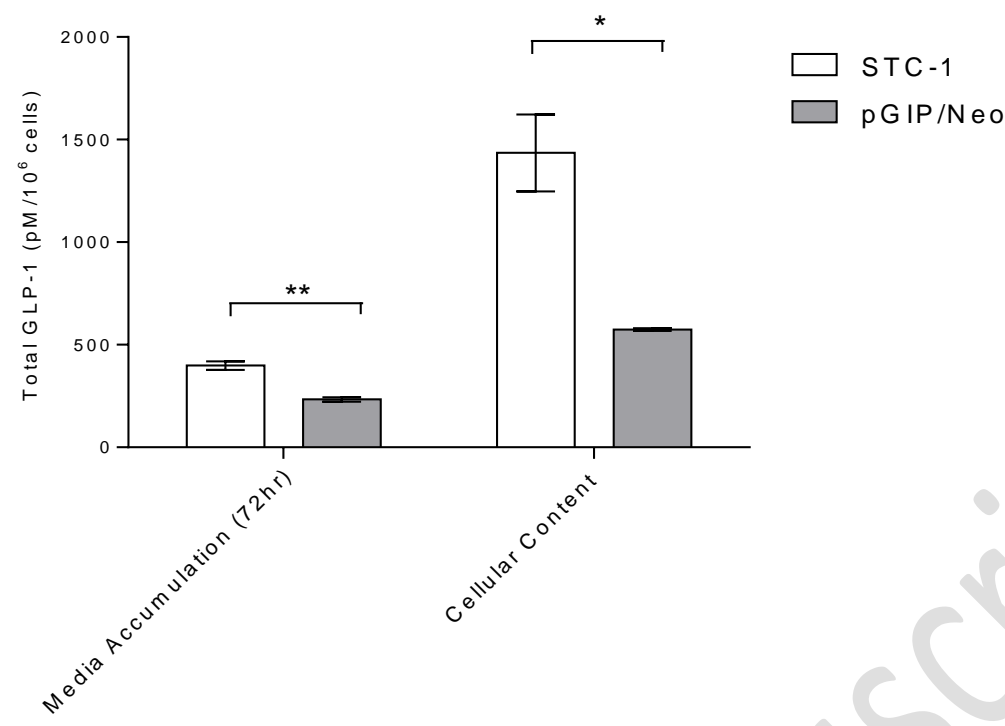

598

599

B

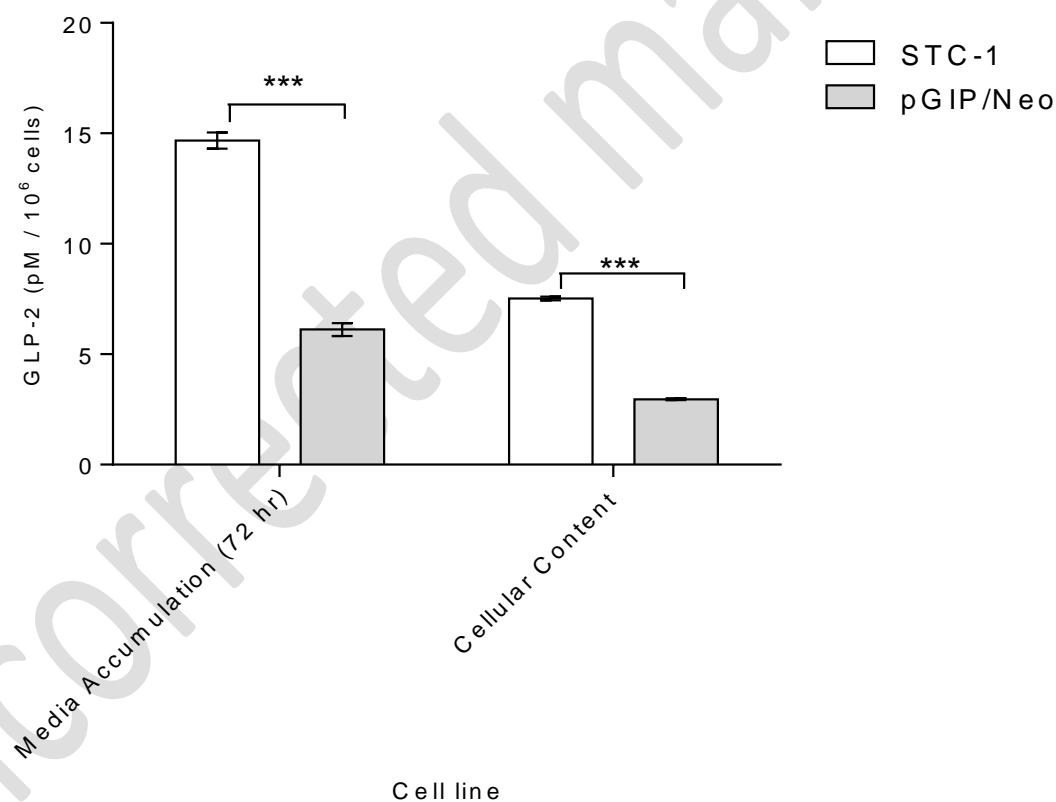

600

601 Figure 2. Comparative levels of GLP-1 and GLP-2 in STC-1 and pGIP/neo cell lines. The media 602 accumulation (over 72h) and cellular content from cells were measured for (A) Total GLP-1 (active (7603 36) and inactive (9-36)) and (B) Total GLP-2 measured by ELISA (mean \pm SEM, $n=3$ ). Statistical 604 differences were determined by unpaired two-tailed t-test; ${ }^{*} P \leq 0.05, * * P \leq 0.01$ and $* * * P \leq 0.001$.

605 


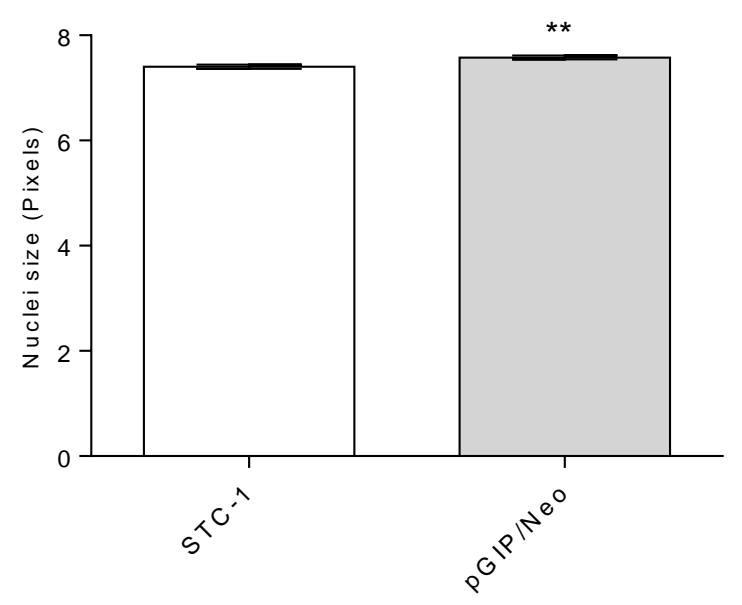

Cell line

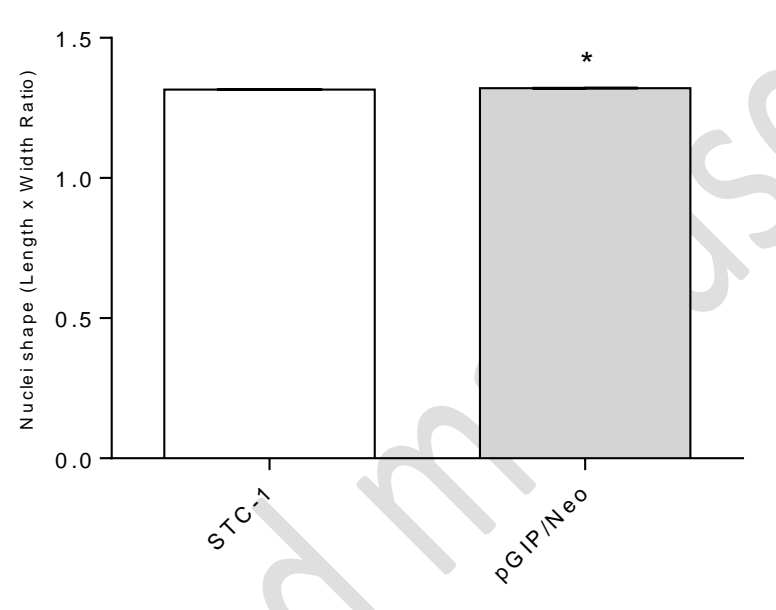

Cell line

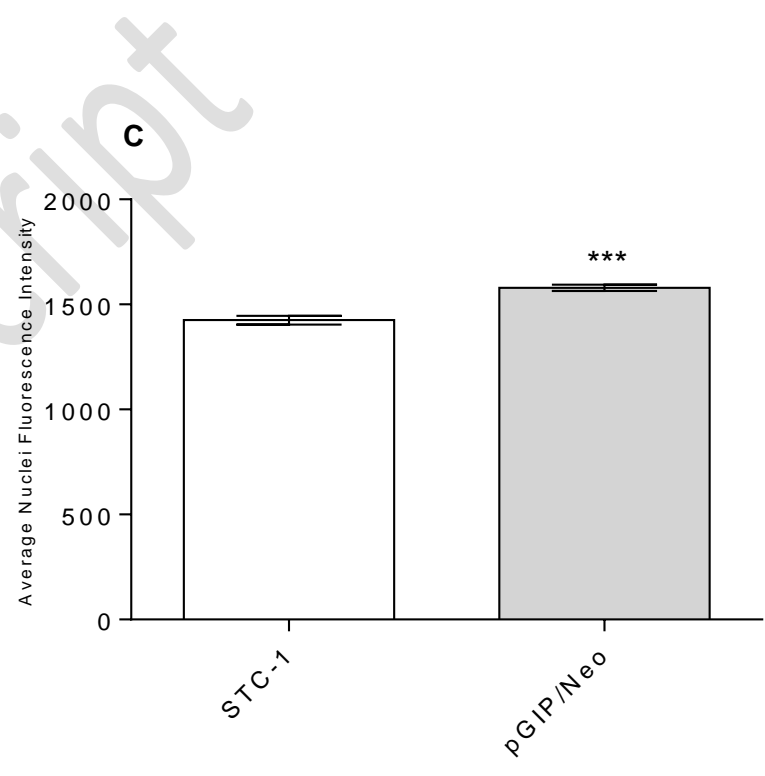

C ell line
608

Figure 3. Morphometric differences between STC-1 and pGIP/Neo cell lines. High Content Analysis detected modest but significant differences in the (A) nuclei size, (B) nuclei shape, and (C) Hoechst (nuclear) staining intensity of STC-1 and pGIP/Neo cell lines (mean \pm SEM $n=36$ wells). Statistical differences were determined by unpaired two-tailed t-test; ${ }^{*} \mathrm{P} \leq 0.05,{ }^{*} \mathrm{P} \leq 0.01$ and ${ }^{* * *} \mathrm{P} \leq 0.001$. 
613
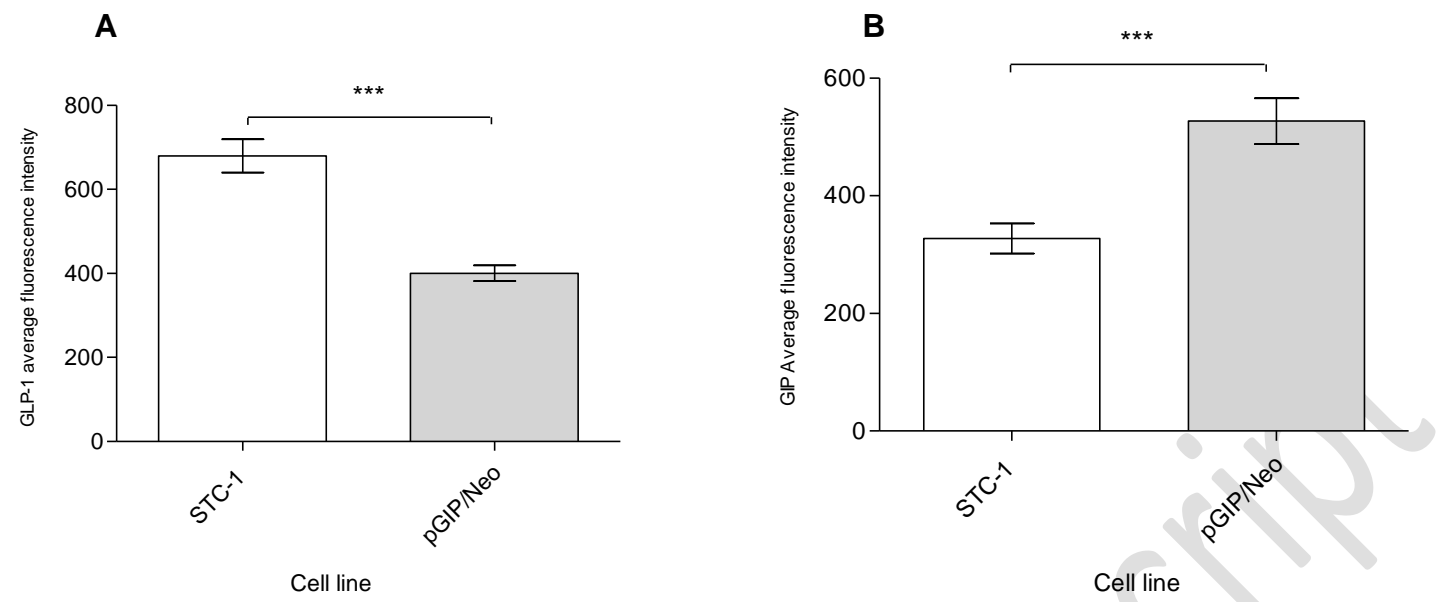

C

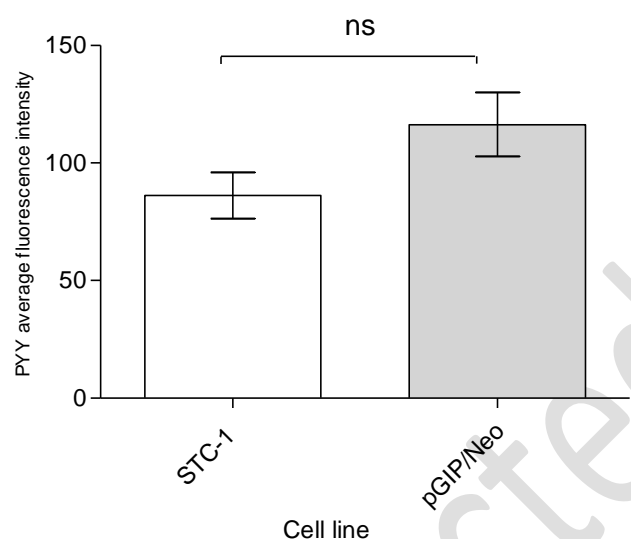

D

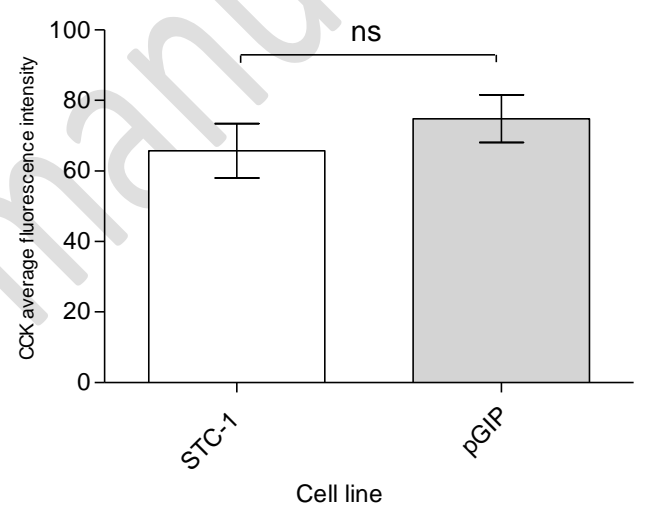

614 Figure 4. Comparison of intestinal hormone immunoreactivity in cell lines. High Content Analysis

615 detected significant differences between STC-1 and pGIP/Neo cell lines in their hormone-specific

616 immunoreactivity for (A) GLP-1 and (B) GIP (mean \pm SEM; $n=9)$. No such differences were detected for

617 (C) PYY and (D) CCK. Statistical differences were determined by unpaired two-tailed t-test; $618 \quad * * * P \leq 0.001$.

619

620

621

622

623 
A
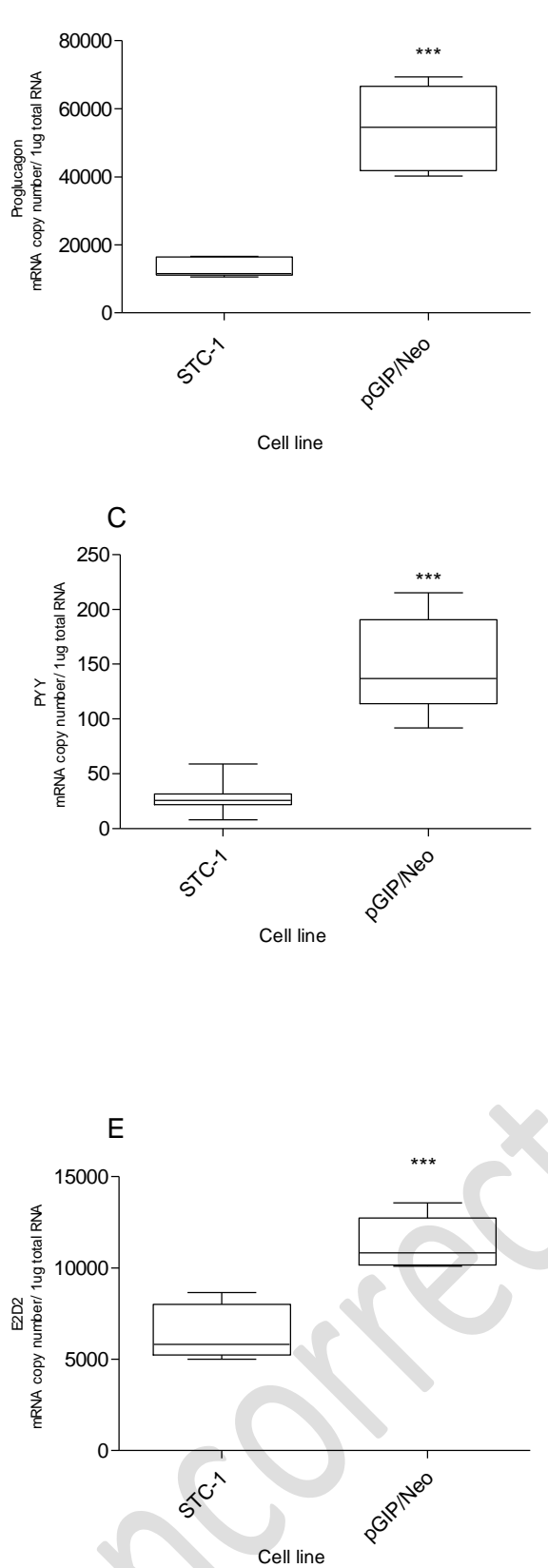

B
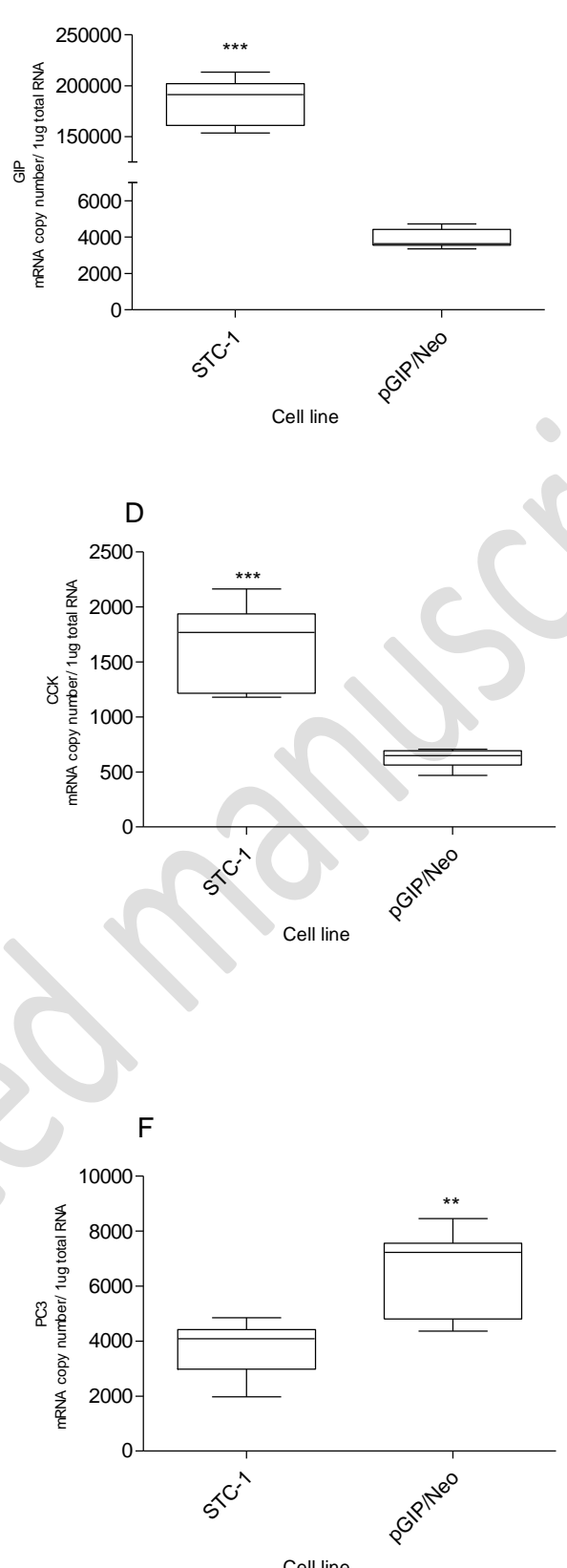

627 Figure 5. Gene transcript differences between STC-1 and pGIP/Neo cell lines. Graphs show mRNA

628 copy number for (A) the proglucagon gene, (B) the glucose-dependent insulinotropic polypeptide 629 gene (GIP), (C) the Polypeptide YY gene (PYY), (D) the cholecystokinin gene (CCK), (E) the Ubiquitin630 conjugating enzyme (E2D2) gene and (F) the Prohormone Convertase 3 gene (PC3) gene. mRNA copy 631 number were determined by qRT-PCR, referenced to the $18 \mathrm{~s}$ gene and expressed as per $\mu \mathrm{g}$ of total 632 RNA (median, min to $\max , \mathrm{n}=9$ ). Statistical differences were determined by unpaired two-tailed t-test; 


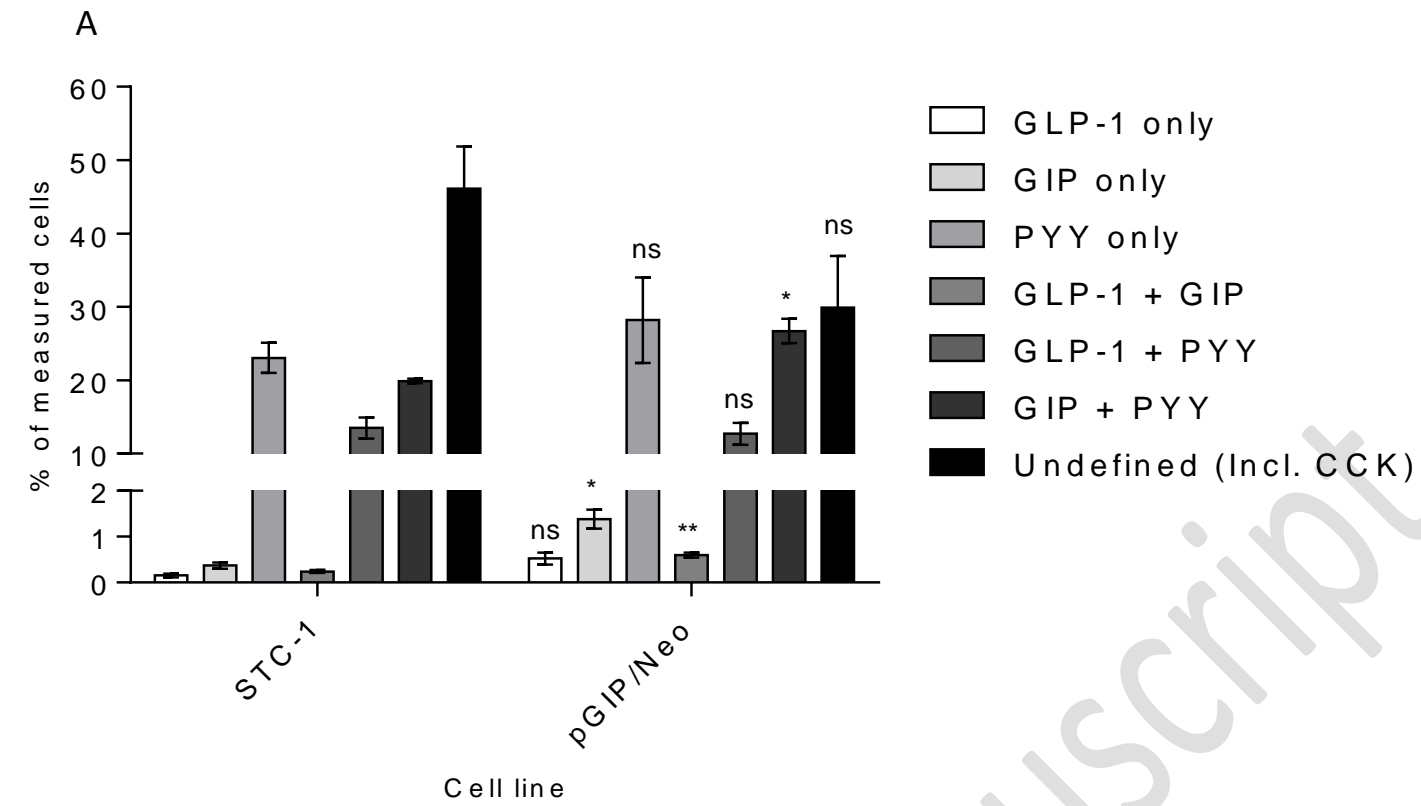

635

B

636

637

638

639

640

641

642

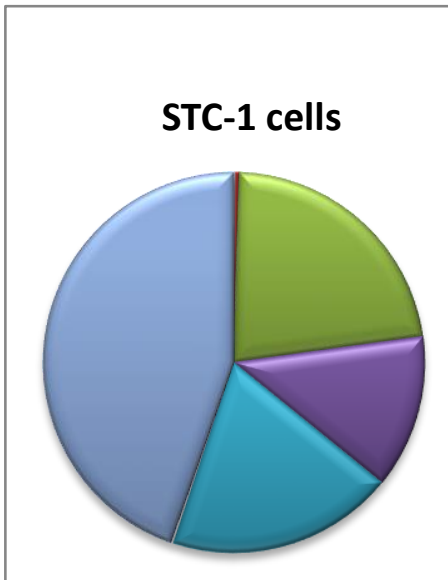

口GLP-1 only

口GIP only

$\checkmark \mathrm{PYY}$ only

G GLP-1 +

PYY

$\square \mathrm{GIP}+\mathrm{PYY}$

G GLP-1 +

GIP

口Undefined

(Incl. CCK)

- GLP-1 only

G GIP only

$\square$ PYY only

口 GLP-1 + PYY

$\square \mathrm{GIP}+\mathrm{PYY}$

$\square$ GLP-1 +

GIP

$\square$ Undefined

(Incl. CCK)

644

645

646 


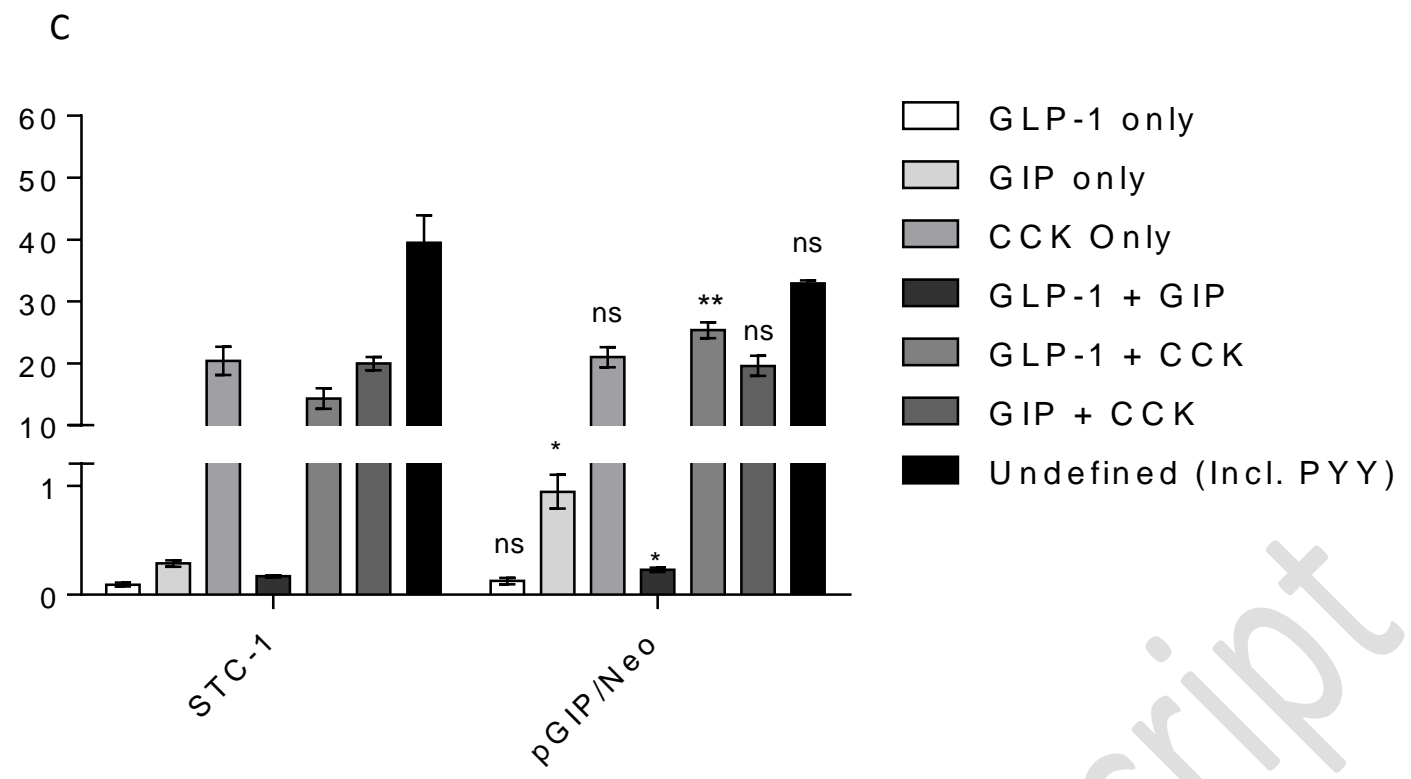

Cell line

647

648

649

650

651

652

653

654

655

656

657

658

659

660

661

662

663

664

665

666

667

668
D

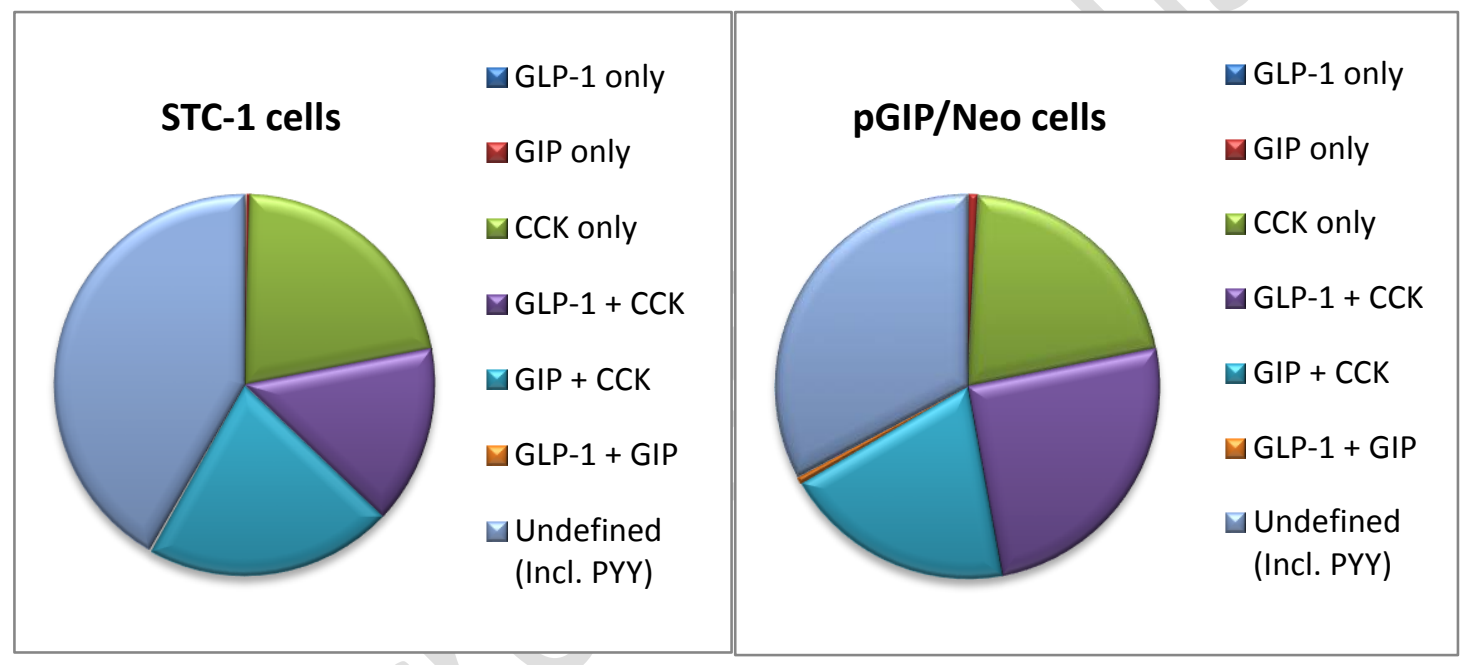

Figure 6. Differences in the proportion of cells of particular hormone immunoreactivities. Following HCA with hormone-specific antibodies classifications were assigned to every individual cell using Boolean commands. Technical constraints meant that PYY and CCK comparisons had to be considered separately 'undefined (Incl. CCK)/ (Incl. PYY)'. Measurements were taken from an average total of 12 350 cells across 6 wells (mean \pm SEM, $n=6$ ). (A \& B) Comparisons of cells with GLP-1, GIP and PYY immunoreactivity. (C \& D) Comparisons of cells with GLP-1, GIP and CCK immunoreactivity. Statistical differences were determined by unpaired two-tailed t-tests; ${ }^{*} \mathrm{P} \leq 0.05 ;{ }^{*} \mathrm{P} \leq 0.01$. Pie charts provide an overview of the abundance of each cell immunoreactivity profile (B \& D). A classification of 'undefined' indicates intensity values below the set threshold or cells that had no immunoreactivity for the hormones tested. 
Figure 7.
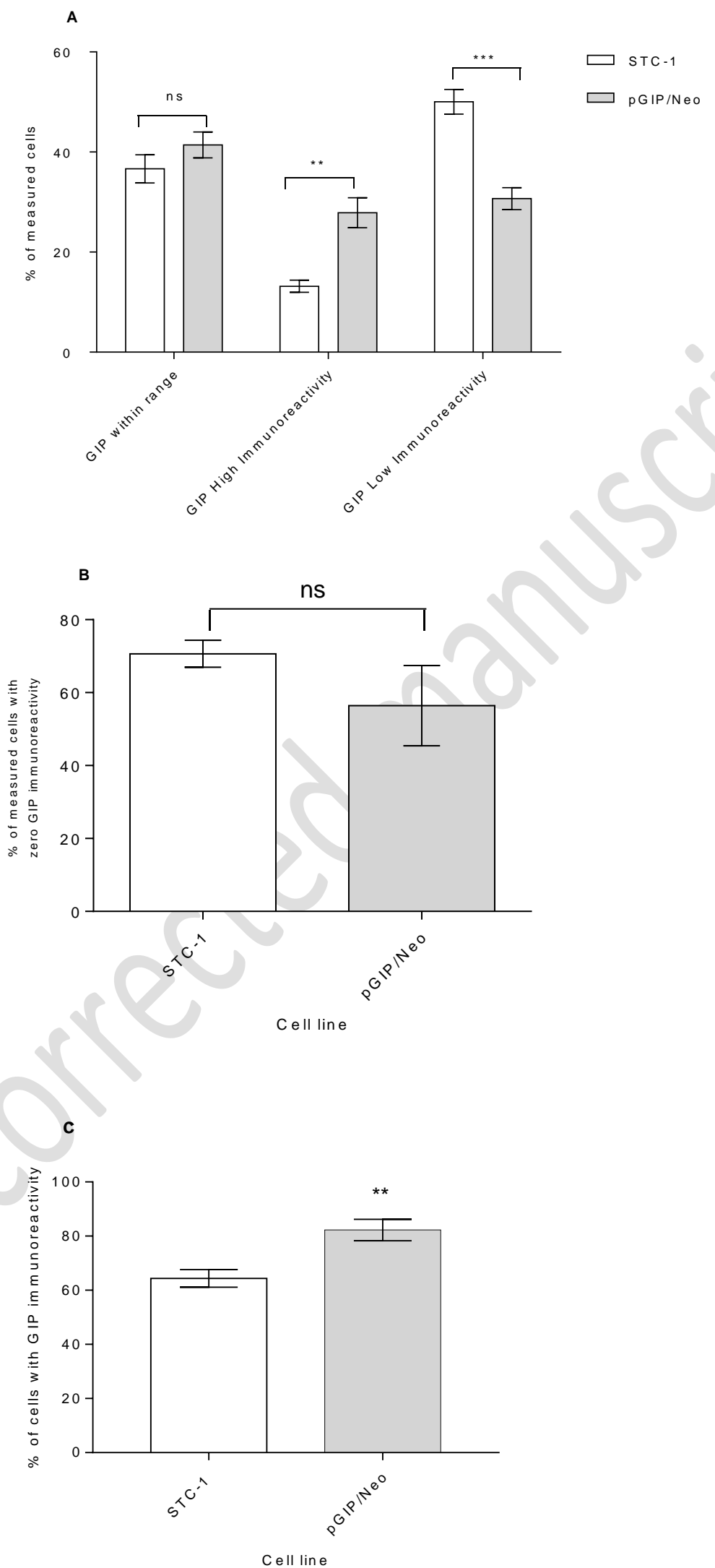
673 number of highly immunoreactive cells. In-depth analysis of GIP immunoreactivity of all cells in 674 individual wells from the STC-1 and pGIP/Neo cell lines (mean \pm SEM, $n=6$ wells). Levels were set in 675 order to define immunoreactivity classification. (A) Average fluorescence intensity was determined 676 and cells with GIP immunoreactivity above the lowest quartile but below the highest quartile were 677 classified as having 'GIP within range' immunoreactivity. Cells with immunoreactivity in the highest 678 or lowest quartiles were classified as having 'high immunoreactivity' or 'low immunoreactivity', 679 respectively. (B) The percentage of 'Low GIP immunoreactivity' cells with zero GIP immunoreactivity. 680 (C) The overall percentage of cells with GIP immunoreactivity in the STC-1 compared with the $681 \mathrm{pGIP} /$ Neo cell lines. Statistical differences were determined by unpaired two-tailed t-tests; ${ }^{*} \mathrm{P} \leq 0.01$; $* * * \mathrm{P} \leq 0.001$.

683 
Supplementary Table 1.

\begin{tabular}{|c|c|c|c|c|c|}
\hline Metabolite & Cell line & Pre-incubation Mean (SEM) & Post-incubation Mean (SEM) & $p$-value & \% Change \\
\hline \multirow{2}{*}{ Propionylcarnitine } & PGIP/Neo & $0.0397( \pm 0.0024)$ & $0.0110( \pm 0.0032)$ & ** & -72.27 \\
\hline & STC-1 & $0.0543( \pm 0.0033)$ & $0.0293( \pm 0.0025)$ & $\cdots *$ & -46.02 \\
\hline \multirow{2}{*}{ Alanine } & PGIP/Neo & $533.00( \pm 4.51)$ & $1149.00( \pm 52.10)$ & $* * *$ & 115.57 \\
\hline & STC-1 & $956.70( \pm 22.52)$ & $1049.00( \pm 18.49)$ & $\cdot$ & 9.65 \\
\hline \multirow{2}{*}{ Arginine } & PGIP/Neo & $100.70( \pm 0.33)$ & $74.40( \pm 2.24)$ & $* * *$ & -26.12 \\
\hline & STC-1 & $68.62( \pm 2.67)$ & $67.32( \pm 1.13)$ & ns & -1.89 \\
\hline \multirow{2}{*}{ Citrulline } & pGIP/Neo & $2.51( \pm 0.1054)$ & $2.21( \pm 0.2038)$ & ns & -11.83 \\
\hline & STC-1 & $3.42( \pm 0.2494)$ & $2.60( \pm 0.1094)$ & ${ }^{*}$ & -23.85 \\
\hline \multirow{2}{*}{ Glutamine } & PGIP/Neo & $642.30( \pm 8.67)$ & $487.31( \pm 31.00)$ & $* *$ & -24.13 \\
\hline & STC-1 & $970.30( \pm 44.10)$ & $547.52( \pm 10.77)$ & $* * *$ & -43.57 \\
\hline \multirow{2}{*}{ Glutamic acid } & PGIP/Neo & $21.02( \pm 0.2186)$ & $37.33( \pm 2.03)$ & $*$ & 77.51 \\
\hline & STC-1 & $41.82( \pm 2.10)$ & $47.32( \pm 1.57)$ & ns & 13.15 \\
\hline \multirow{2}{*}{ Glycine } & pGIP/Neo & $112.00( \pm 2.89)$ & $127.32( \pm 1.76)$ & $\cdot$ & 13.66 \\
\hline & STC-1 & $113.61( \pm 4.62)$ & $116.00( \pm 1.24)$ & ns & 2.11 \\
\hline \multirow{2}{*}{ Histidine } & PGIP/Neo & $51.63( \pm 0.8413)$ & $44.10( \pm 1.14)$ & ** & -14.58 \\
\hline & STC-1 & $49.13( \pm 1.75)$ & $40.91( \pm 0.3376)$ & ** & -16.75 \\
\hline \multirow{2}{*}{ lleucine } & PGIP/Neo & $194.31( \pm 6.39)$ & $159.33( \pm 0.88)$ & $*$ & -18.01 \\
\hline & STC-1 & $182.82( \pm 7.45)$ & $153.00( \pm 4.28)$ & $* *$ & -16.30 \\
\hline \multirow{2}{*}{ Leucine } & PGIP/Neo & $229.31( \pm 8.67)$ & $199.00( \pm 21.13)$ & ns & -13.21 \\
\hline & STC-1 & $222.00( \pm 5.49)$ & $171.32( \pm 8.65)$ & $* * *$ & -22.84 \\
\hline \multirow{2}{*}{ Lysine } & pGIP/Neo & $247.35( \pm 2.96)$ & $167.00( \pm 4.36)$ & $* * *$ & -32.47 \\
\hline & STC-1 & $235.77( \pm 8.99)$ & $135.36( \pm 3.38)$ & $* * *$ & -42.60 \\
\hline \multirow{2}{*}{ Methionine } & PGIP/Neo & $44.47( \pm 1.01)$ & $39.47( \pm 0.5457)$ & ${ }^{*}$ & -11.24 \\
\hline & STC-1 & $41.95( \pm 1.40)$ & $35.17( \pm 0.7684)$ & $* *$ & -16.16 \\
\hline \multirow{2}{*}{ Ornithine } & PGIP/Neo & $17.60( \pm 0.4933)$ & $15.33( \pm 0.8327)$ & ns & -13.07 \\
\hline & STC-1 & $45.17( \pm 1.51)$ & $19.07( \pm 0.3721)$ & $* * *$ & -57.72 \\
\hline Phenylalanine & pGIP/Neo & $95.07( \pm 1.97)$ & $89.73( \pm 0.5897)$ & ns & -5.62 \\
\hline Pnenyialanine & STC-1 & $86.52( \pm 2.88)$ & $84.95( \pm 1.22)$ & ns & -1.81 \\
\hline Proline & pGIP/Neo & $4.30( \pm 0.5633)$ & $106.40( \pm 8.07)$ & $* *$ & 2376.15 \\
\hline & STC-1 & $8.76( \pm 0.3587)$ & $72.25( \pm 1.58)$ & $* * *$ & 724.49 \\
\hline & pGIP/Neo & $108.00( \pm 4.04)$ & $128.31( \pm 3.71)$ & $*$ & 18.80 \\
\hline Serine & STC-1 & $102.46( \pm 3.59)$ & $117.00( \pm 3.30)$ & $*$ & 14.26 \\
\hline Threonine & pGIP/Neo & $170.77( \pm 2.03)$ & $163.36( \pm 5.55)$ & ns & -4.34 \\
\hline Niveormine & STC-1 & $159.00( \pm 3.87)$ & $155.00( \pm 2.11)$ & ns & -2.52 \\
\hline Truntonhan & pGIP/Neo & $18.77( \pm 0.5364)$ & $16.83( \pm 0.0882)$ & $\cdot$ & -10.34 \\
\hline Irypropian & STC-1 & $17.35( \pm 0.5720)$ & $16.27( \pm 0.1838)$ & ns & -6.22 \\
\hline & PGIP/NeO & $98.83( \pm 2.73)$ & $88.57( \pm 0.4910)$ & $\cdot$ & -10.38 \\
\hline Tyrosine & STC-1 & $86.03( \pm 2.90)$ & $82.28( \pm 2.14)$ & ns & -4.36 \\
\hline Valine & pGIP/Neo & $203.00( \pm 3.79)$ & $181.38( \pm 2.96)$ & $\cdot$ & -10.69 \\
\hline Valine & STC-1 & $193.00( \pm 6.38)$ & $165.29( \pm 2.15)$ & $* *$ & -14.40 \\
\hline Asymmetric dimethylarginine (ADMA) & pGIP/Neo & $0.2523( \pm 0.1263)$ & $0.6340( \pm 0.0854)$ & ns & 151.29 \\
\hline 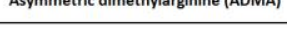 & STC-1 & $0.2595( \pm 0.0834)$ & $0.4652( \pm 0.1182)$ & ns & 79.27 \\
\hline Alpha-aminoadipic acid (alpha-AAA) & PGIP/Neo & $0.4427( \pm 0.0269)$ & $0.3155( \pm 0.0065)$ & $\cdot$ & -28.73 \\
\hline & STC-1 & $0.5292( \pm 0.0577)$ & $0.5030( \pm 0.0522)$ & ns & -4.95 \\
\hline & PGIP/Neo & $0.7347( \pm 0.1011)$ & $0.58( \pm 0.0702)$ & ns & -21.06 \\
\hline Carnosine & STC-1 & $1.26( \pm 0.0356)$ & $1.02( \pm 0.0279)$ & $* * *$ & -18.73 \\
\hline Creatinine & pGIP/Neo & $5.41( \pm 0.8320)$ & $5.14( \pm 0.2810)$ & ns & -4.99 \\
\hline Codedinine & STC-1 & $7.73( \pm 0.2349)$ & $7.49( \pm 0.6283)$ & ns & -3.22 \\
\hline Kynurenine & pGIP/Neo & $0.29( \pm 0.0246)$ & $0.28( \pm 0.0185)$ & ns & -4.97 \\
\hline & STC-1 & $0.37( \pm 0.0235)$ & $0.41( \pm 0.0272)$ & ns & 11.70 \\
\hline Methionine sulfoxide (Met-SO) & pGIP/Neo & $1.42( \pm 0.1317)$ & $1.16( \pm 0.1184)$ & ns & -18.50 \\
\hline Mietnionine surfoxide (iviet-s0) & STC-1 & $1.07( \pm 0.1539)$ & $0.6418( \pm 0.1186)$ & ns & -40.24 \\
\hline t4-hydroxyproline (t4-OH-Pro) & PGIP/Neo & $2.44( \pm 0.0984)$ & $3.11( \pm 0.1102)$ & $\cdot$ & 27.46 \\
\hline & STC-1 & $4.61( \pm 0.1651)$ & $5.44( \pm 0.0488)$ & $* *$ & 18.02 \\
\hline Taurine & pGIP/Neo & $2.52( \pm 0.3803)$ & $1.107( \pm 0.1562)$ & $\cdot$ & -56.07 \\
\hline Taurine & STC-1 & $3.99( \pm 0.1126)$ & $8.16( \pm 0.1790)$ & $\cdots$ & 104.72 \\
\hline Symmetric dimethylarginine (SDMA) & $\mathrm{pGIP} / \mathrm{Neo}$ & $0.2947( \pm 0.0292)$ & $0.5093( \pm 0.0875)$ & ns & 72.82 \\
\hline 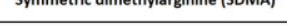 & STC-1 & $0.5453( \pm 0.1406)$ & $0.3380( \pm 0.1415)$ & ns & -38.02 \\
\hline & pGIP/Neo & $5349.00( \pm 262.70)$ & $2123.00( \pm 35.36)$ & $\cdots$ & -60.31 \\
\hline Glucose & STC-1 & $5231.00( \pm 192.00)$ & $1793.00( \pm 41.14)$ & $\cdots$ & -65.72 \\
\hline Total Amino Acids & PGIP/Neo & $145.81( \pm 21.65)$ & $165.72( \pm 32.43)$ & ns & 13.65 \\
\hline Iotal Amino Acids & STC-1 & $193.00( \pm 6.38)$ & $165.20( \pm 2.15)$ & ns & -14.40 \\
\hline Essential Amino Acids & pGIP/Neo & $135.00( \pm 14.75)$ & $115.00( \pm 11.91)$ & ns & -14.81 \\
\hline & STC-1 & $131.91( \pm 10.96)$ & $106.32( \pm 8.14)$ & ns & -19.41 \\
\hline Branched Chain Amino Acids & PGIP/Neo & $208.97( \pm 6.21)$ & $179.92( \pm 8.42)$ & $\cdot$ & -13.88 \\
\hline & STC- 1 & $199.32( \pm 5.34)$ & $163.28( \pm 3.61)$ & $\cdots *$ & -18.11 \\
\hline
\end{tabular}

707 (mean \pm SEM; $n=3-6$ wells of the same passage number). Negative percentage values indicate decreased metabolite levels after incubation (i.e. nutrient utilisation). Positive percentage values were also observed indicating increased metabolite levels after incubation (i.e. metabolite production).

710 Statistical differences were determined by unpaired two-tailed t-tests; ${ }^{*} P \leq 0.05,{ }^{* *} P \leq 0.01$ and 